\title{
Sapindaceae na Serra Negra, Minas Gerais, Brasil
}

Sapindaceae in the Serra Negra, Minas Gerais, Brazil

Joana Miloski ${ }^{1}$, Genise V. Somner ${ }^{2,4}$, Fátima R.G. Salimena ${ }^{3}$ \& Luiz Menini Neto ${ }^{3}$

\begin{abstract}
Resumo
A Serra Negra faz parte da formação Mantiqueira que pertence ao domínio Atlântico, e é composta por um mosaico de vegetação de campos rupestres e diferentes tipos florestais. Localiza-se na região sul da Zona da Mata mineira (21 $58^{\prime}$ 'S e $43^{\circ} 53^{\prime}$ W), entre os municípios de Lima Duarte, Olaria, Rio Preto e Santa Bárbara do Monte Verde. Sapindaceae está representada nesta serra por cinco gêneros e 14 espécies: Allophylus semidentatus, Cupania ludowigii, C. vernalis, Matayba juglandifolia, M. marginata, Paullinia carpopoda, P. trigonia, Serjania deflexa, S. elegans, S. fuscifolia, S. laruotteana, S. laxiflora, S. multiflora e S. reticulata. Dentre as espécies estudadas destaca-se S. laxiflora como endêmica do estado de Minas Gerais. Allophylus semidentatus, C. vernalis, $P$. trigonia, S. fuscifolia, S.laruotteana e S. reticulata apresentam ampla distribuição geográfica. No presente trabalho é apresentado o tratamento taxonômico da família, incluindo chave de identificação, descrições, ilustrações, distribuição geográfica e comentários sobre as espécies.
\end{abstract}

Palavras-chave: campo rupestre, flora, Floresta Atlântica, Serra da Mantiqueira, Zona da Mata.

\begin{abstract}
Serra Negra is part of the Mantiqueira mountain range within the Atlantic domain and is composed of a vegetation mosaic of campos rupestres and different forest types. It lies in the southern part of the Zona da Mata (21 $58^{\prime} 24^{\prime}$ 'S e 4353'15' 'W, within the municipalities of Lima Duarte, Olaria, Rio Preto and Santa Bárbara do Monte Verde. The Sapindaceae family is represented in this area by five genera and 14 species: Allophylus semidentatus, Cupania ludowigii, C. vernalis, Matayba juglandifolia, M. marginata, Paullinia carpopoda, P. trigonia, Serjania deflexa, S. elegans, S. fuscifolia, S. laruotteana, S. laxiflora, S. multiflora and Serjania reticulata. Among these, S. laxiflora stands out as an endemic species of Minas Gerais. Allophylus semidentatus, C. vernalis, P. trigonia, S. fuscifolia, S. laruotteana and S. reticulata have wide geographic distributions. A taxonomic treatment of the family in this area is presented, including an identification key, morphological descriptions, illustrations, geographical distributions and commentary on each species.
\end{abstract}

Key words: campo rupestre, flora, Atlantic Forest, Serra da Mantiqueira, Zona da Mata of Minas Gerais.

\section{Introdução}

Sapindaceae é uma família monofilética (Acevedo-Rodríguez 1993; Gadek et al. 1996; Harrington et al. 2005; Buerki et al. 2009) e pertence à ordem Sapindales (APG IV 2016). É predominantemente tropical e subtropical, ocorrendo raros gêneros em países temperados (Somner 2001; Judd et al. 2009; AcevedoRodríguez et al. 2010). Dentre os gêneros ocorrentes no Novo Mundo, Allophylus L. (250), Cupania L. (50), Matayba Aubl. (50), Paullinia L. (190), Serjania Mill. (230) e Talisia Aubl. (52), se destacam pelo número de espécies (AcevedoRodríguez et al. 2010). Apresenta 141 gêneros e aproximadamente 2000 espécies. Na Região Neotropical foram registrados 38 gêneros e cerca de 800 espécies, sendo representadas por árvores, arbustos, lianas ou menos frequente trepadeiras

\footnotetext{
${ }^{1}$ Universidade Federal de Juiz de Fora - ICB, Campus Universitário, R. José Lourenço Kelmer s/n, São Pedro, 36036900, Juiz de Fora, MG, Brasil.

${ }^{2}$ Universidade Federal Rural do Rio de Janeiro, Inst. Biologia, Depto. Botânica, Rod. BR465-Km 7, UFRRJ, C.P. 74582, 23890000, Seropédica, RJ, Brasil.

${ }^{3}$ Universidade Federal de Juiz de Fora - Botânica, ICB - Campus Universitário, R. José Lourenço Kelmer s/n, São Pedro, 36036900, Juiz de Fora, MG, Brasil.

${ }^{4}$ Autor para correspondência: genisesomner@gmail.com
} 
herbáceas (Acevedo-Rodríguez 2012). No Brasil ocorrem 28 gêneros e 418 espécies, sendo 190 endêmicas, com distribuição em todos os domínios geográficos destacando-se a Floresta Amazônica e a Floresta Atlântica (BFG 2015).

Apesar de Minas Gerais apresentar elevada riqueza de Sapindaceae (134 spp.) (BFG 2015), poucos estudos específicos sobre a família foram realizados no estado, como em Grão Mogol (Ferrucci 2006) e na Serra do Cipó (Silva et al. 2013).

A Floresta Atlântica está reduzida a pouco mais de 4\% de sua cobertura original em Minas Gerais, dos quais $20 \%$ está localizado na Serra da Mantiqueira, cuja maior área está distribuída neste estado. Para conservar essa riqueza, foi criado o Corredor Ecológico da Mantiqueira (Costa \& Herrmann 2006), onde está incluída a Serra Negra, que é atualmente considerada prioritária para a conservação da biodiversidade de Minas Gerais, devido à elevada riqueza e grau de endemismo de espécies da sua fauna e flora (Drummond et al. 2005). Salimena et al. (2013) realizaram estudo florístico na região registrando 1033 espécies, 169 gêneros e 119 famílias de fanerógamas, além de 210 espécies de pteridófitas (Souza et al. 2012). Dentre as fanerógamas 58 espécies são citadas na lista de espécies ameaçadas do estado de Minas Gerais, sendo cinco endêmicas para a região (Salimena et al. 2013).

Este trabalho tem como objetivo o tratamento taxonômico das espécies de Sapindaceae ocorrentes na Serra Negra, relacionando habitat, distribuição geográfica e fenologia das espécies encontradas.

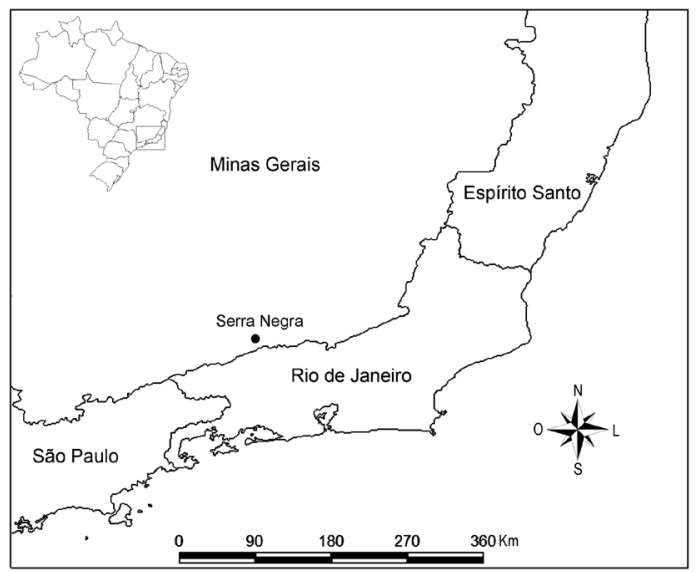

Figura 1 - Localização da Serra Negra, Minas Gerais, Brasil.

Figure 1 - Location of the Serra Negra, Minas Gerais, Brazil.
Espera-se desta forma, contribuir para enriquecer o conhecimento sobre a flora da Serra Negra, bem como da Serra da Mantiqueira.

\section{Material e Métodos}

A Serra Negra está localizada em Minas Gerais, na região sul da Zona da Mata com aproximadamente 10.000 hectares (Souza et al. 2012) e 15 km de extensão, (21 ${ }^{\circ} 58^{\prime} \mathrm{S}$ e $43^{\circ} 53^{\prime} \mathrm{W}$ ), integrando o Complexo da Mantiqueira, sob o domínio Atlântico (Fig. 1). Possui cotas altimétricas entre 800 e ca. $1700 \mathrm{~m}$ e está limitada com os municípios de Lima Duarte (ao norte), Rio Preto (ao sul), Santa Bárbara do Monte Verde (a leste), e Olaria (a oeste), próximo a divisa com o estado do Rio de Janeiro (Menini Neto et al. 2009; Salimena et al. 2013). Dados sobre o clima e vegetação da região são encontrados em Salimena et al. (2013).

Coletas de exemplares férteis foram realizadas sistematicamente procurando seguir o período de um mês entre os trabalhos de campo, entre 2003 e 2013, explorando todos os ambientes da Serra Negra pelo método de caminhamento (Filgueiras et al. 1994). Os espécimes foram herborizados, tombados e incorporados ao acervo do herbário CESJ da Universidade Federal de Juiz de Fora (UFJF), e identificados por meio de chaves analíticas e bibliografia especializada (Radlkofer 1931-1934; Reitz 1980; Ferrucci 1991, 2006; Guarim Neto 1994; Guarim Neto \& Santana 2000; Somner et al. 2009b). Dados sobre a distribuição geográfica foram obtidos em BFG (2015).

Neste trabalho a descrição da família foi elaborada de acordo com as espécies aqui tratadas e seguiu Somner et al. (2009b) e Acevedo-Rodríguez et al. (2010). A descrição do indumento das estruturas de cada espécime examinado seguiu Radford (1974). Os nomes populares das espécies foram obtidos através de bibliografia especializada (Radlkofer 1931-1934; Reitz 1980; Somner et al. 2009a; Somner et al. 2009b; BFG 2015).

\section{Resultados e Discussão}

Na Serra Negra Sapindaceae está representada por cinco gêneros que englobam 14 espécies, a saber: Allophylus semidentatus (Miq.) Radlk., Cupania ludowigii Somner \& Ferrucci, C. vernalis Cambess., Matayba juglandifolia (Cambess.) Radlk., M. marginata Radlk., Paullinia carpopoda Cambess., P. trigonia Vell., Serjania deflexa Gardner., S. elegans Cambess, S. fuscifolia Radlk., $S$. laruotteana Cambess., S. laxiflora Radlk., $S$. multiflora Cambess. e $S$. reticulata Cambess. 
Sapindaceae Juss., Ann. Mus. Natl. Hist. Nat. 18: 476. 1811.

Árvores, arvoretas ou trepadeiras lenhosas com gavinhas; monoicas ou raro dioicas; lactescentes ou não, caule cilíndrico, estriado, costado ou sulcado, em seção transversal, nas trepadeiras, com um único cilindro vascular ou um cilindro vascular central e 1-10 cilindros vasculares periféricos. Folhas alternas, compostas trifolioladas ou pinadas, com folíolo terminal reduzido a um apículo, exceto nas trepadeiras; estípulas presentes apenas nas trepadeiras; folíolos com margem geralmente serreado-denteada ou inteira, com ou sem domácias na face abaxial, entre a nervura primárias e secundárias. Inflorescência axilar ou terminal, tirsos ramificados ou não, ou paniculiformes, as trepadeiras apresentam sinflorescências frondoso-bracteosas ou bracteosas, com tirsos racemiformes ou espiciformes. Flores actinomorfas ou zigomorfas, funcionalmente unissexuadas, as estaminadas geralmente com pistilódio, as pistiladas com estaminódios, raro bissexuadas; cálice 4(5)-mero, sépalas côncavas, livres ou conatas; corola 4(5)-mera, brancas ou branco-amareladas, livres, geralmente com apêndice basal petaloide, adnato ou conivente à pétala, nas trepadeiras, com exceção do gênero Thinouia, no ápice do apêndice ocorre uma crista amarela, carnosa, e na base desta projeta-se uma lígula deflexa, vilosa; nectários florais extraextaminais em forma de disco anelar, unilateral, ou fragmentado formando dois ou quatro lobos (dois posteriores e dois laterais), de formas variadas; androceu cêntrico ou excêntrico; estames 8 , livres ou conatos na base, filiformes, anteras dorsifixas, bitecas, rimosas; estaminódios 8 , anteras indeiscentes; gineceu cêntrico ou excêntrico, ovário súpero, gamocarpelar, (2-)3-carpelar, (2) 3-locular, lóculos uniovulados, placentação axial; estilete terminal, 2-3 lobados, lobos unidos; estigma 2-3 ramificado, ou capitado. Frutos cápsulas loculicidas ou septífragas, esquizocarpos com três mericarpos samaroides ou 1-2-mericarpos drupáceos; sementes sem ala, com ou sem arilo ou sarcotesta; embrião sem endosperma, notorrizo, com cotilédones crassos, subretos, curvos ou plicados, eixo radícula-hipocótilo curto, geralmente alojado em uma dobra do tegumento.

\section{Chave para identificação das espécies de Sapindaceae na Serra Negra, Minas Gerais}

1. Árvores ou arvoretas.

2. Folhas trifolioladas; flores zigomorfas; lobos nectaríferos 4; fruto esquizocárpico com 1-2 mericarpos drupáceos, avermelhados; sementes envolvidas por mesocarpo sulcoso.

1. Allophylus semidentatus

2'. Folhas paripinadas, com folíolo abortado no ápice da raque; flores actinomorfas; disco nectarífero anelar; frutos cápsula loculicida; sementes envolvidas por arilo carnoso.

3. Abertura precoce das flores; sépalas conatas, caducas no fruto.

4. Raque foliar subcilíndrica ou bicanaliculada; folíolos 4,5-15 cm compr., quando secos verde amarelados na face adaxial, domácias em bolsas na face abaxial; apêndice das pétalas de tamanho semelhante ou menor que as mesmas; cápsulas verrucosas; arilo recobrindo totalmente a semente.

4. Matayba juglandifolia

4'. Raque foliar marginada ou subalada; folíolos 2-3 cm compr., quando secos castanho claros ou verde escuros na face adaxial, domácias foveoladas ou urceoladas; apêndice das pétalas ultrapassando o tamanho das mesmas; cápsulas rugosas; arilo recobrindo $2 / 3$ da semente

5. Matayba marginata

3'. Abertura não precoce das flores; sépalas livres, persistentes no fruto.

5. Folíolos com margem inteira; cápsula obtriangular ou cordiforme, achatada lateralmente, epicarpo rugoso, glabro; arilo com dois apêndices lineares na base da semente.

2. Cupania ludowigii

5'. Folíolos com margem denteado-serreada; cápsula trígono-obovoide ou trígono-piriforme, não achatada lateralmente, epicarpo tuberculado-rugoso, densamente pubérulo; arilo sem apêndices lineares na base da semente

3. Cupania vernalis

1'. Trepadeiras lenhosas.

6. Fruto cápsula septífraga, crustácea ou subcoriácea, alada ou globosa. 
7. Folíolos com margem inteira; cápsula globosa, crustácea, com estípite 0,9-2 cm compr.; sarcotesta cobre quase ou totalmente a semente; cotilédones subretos 6. Paullinia carpopoda

7'. Folíolos com margem denteado-serreada; cápsula trialada ou tricarenada, subcoriácea, com estípite 0,1-0,5 cm compr.; sarcotesta cobrindo $1 / 2$ a $2 / 3$ da semente; cotilédone externo curvo e interno biplicado.

7. Paullinia trigonia

6'. Fruto esquizocárpico, constituído por três mericarpos samaroides.

8. Caule em seção transversal com apenas um cilindro vascular.

9. Caule geniculado; margem dos folíolos denteado-serreada em 1/2-1/3 distal, bidentada logo abaixo do ápice, folíolos com face adaxial opaca; anteras rostradas; lobos nectários posteriores ovoides; sementes trígono-obovoides ..... 14. Serjania reticulata

9'. Caule não geniculado; margem dos folíolos inteira ou com 2-3 dentes na porção distal, folíolos com face adaxial brilhosa; anteras não rostradas; lobos nectariferos posteriores subesféricos; sementes lenticulares, glabras....

12. Serjania laxiflora

8'. Caule com cilindro vascular central bem pequeno e com cinco cilindros vasculares radiais, ou caule com cilindro vascular central e com 7 a 10 cilindros vasculares periféricos menores ao redor do central.

10. Caule em seção transversal composto por um cilindro vascular central bem pequeno e cinco cilindros vasculares radiais

12. Caule e porção seminífera dos mericarpos samaroides pubérulos, com tricomas glandulares; folíolos com face adaxial e abaxial pubescentes, com domácias pilosas; corola rósea; lobos nectaríferos posteriores subesféricos 9. Serjania elegans

12'. Caule e porção seminífera dos mericarpos denso-setoso-hirsutos; folíolos com face adaxial setosa e com tricomas glandulares, face abaxial lanuginosa; face abaxial sem domácias; corola branca; lobos nectaríferos posteriores ovoides

10'. Caule em seção transversal composto por um cilindro central e 7-10 cilindros vasculares periféricos ao redor do central.

13. Estípulas oblongas, caducas, cicatrizes semilunares; mericarpos samaroides com porção seminífera achatada lateralmente 11. Serjania laruotteana

13'. Estípulas subuladas ou triangulares, persistentes; mericarpos samaroides com a porção seminífera inflada.

14. Estípulas triangulares; margem dos folíolos crenado-serreada, face abaxial com domácias entre as nervuras primárias e secundárias; cincinos pedunculados; sementes pubérulas na base. 10. Serjania fuscifolia

14'. Estípulas subuladas; margem dos folíolos denteado-serreada, face abaxial sem domácias; cincinos subsésseis; sementes glabras 13. Serjania multiflora

1. Allophylus semidentatus (Miq.) Radlk., in Engl. \&. Prantl, Nat. Pflanzenfam. 3(5): 312. 1895.

Fig. 2a

Árvore ca. $5 \mathrm{~m}$ alt., ramos subcilíndricos, estriados, lenticelados, glabros. Folhas trifolioladas, 5,7-18 cm compr.; pecíolo canaliculado, 1,7-4,5 cm compr., com tricomas curtos e adpressos, peciólulo terminal $0,5-1 \mathrm{~cm}$ compr.; folíolos elípticos, ovados, ovado-lanceolados, obovados, 1,5-15 × 3,2-6,5 cm, cartáceos, base do folíolo terminal longamente cuneada, cartáceos, ápice acuminado, mucronado ou agudo, margem serreada na metade distal, dentes com ápice acuminado e pilosos, face adaxial glabra ou com tricomas esparsos nas nervuras, face abaxial com tricomas esparsos sobre as nervuras; domácias pilosas. Tirsos axilares, geralmente não ramificados, às vezes com 1-2 ramos basais curtos; pedúnculo $1-3 \mathrm{~cm}$ compr., raque 0,5-12 cm comp., pubescentes; cincinos 3-4-floros; brácteas triangulares, ca. $7 \mathrm{~mm}$ compr., bractéolas semelhantes às brácteas, ca. $3 \mathrm{~mm}$ compr., pubescentes. Flores zigomorfas, 3,5-5 mm compr.; cálice 4-mero, sépalas 1-1,5 mm compr., pubérulas, ciliadas; corola 4-mera, pétalas $1-1,5$ $\mathrm{mm}$, obovadas, apêndice emarginado formando duas linguetas inflexas, curtas e vilosas; lobos nectaríferos 4; androginóforo presente; estames 1,5-2 mm compr., vilosos, pistilódio glabro; 


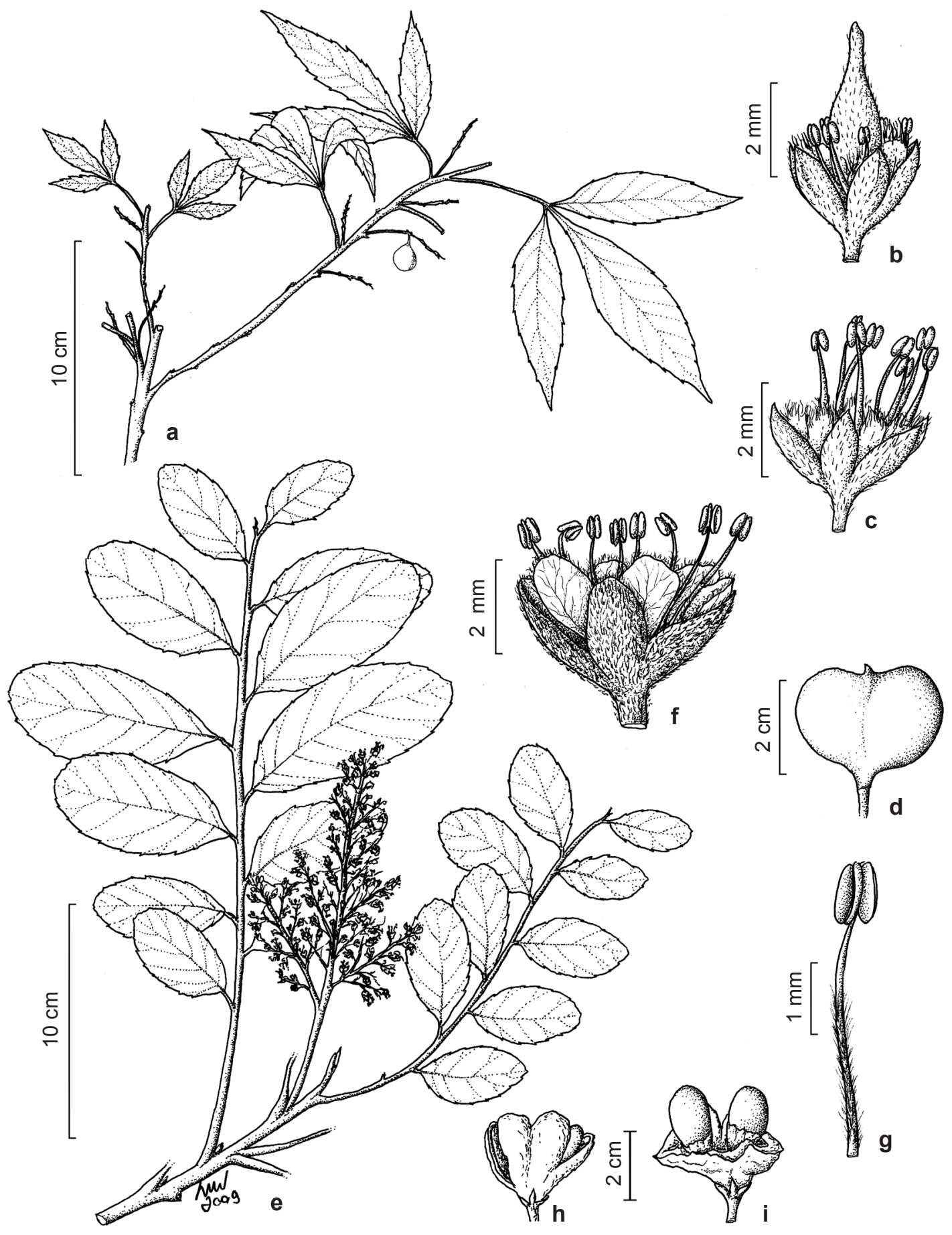

Figura 2 - a. ramo frutífero de Allophylus semidentatus. b-d. Cupania ludowigii - b. flor feminina; c. flor masculina; d. cápsula. e-i. Cupania vernalis - e. ramo florífero; f. flor masculina; g. estame; h. cápsula loculicida semiaberta; i. cápsula loculicida aberta mostrando sementes com arilo. (a. Antunes et al. 58; b-c. Valente et al. 252; d. Valente et al. 350; e-g. Valente et al. 347; h-i. Miloski et al. 1).

Figure 2 - a. Allophyllus semidentatus - branch with fruits. b-e. Cupania ludowigii - b. female flower; c. male flower; d. capsule. e-i. Cupania vernalis - e. branch with flowers; f male flower; g. stamen; h. open loculicidal capsule; i. open loculicidal capsule showing seeds with aril. (a. Antunes et al. 58; b-c. Valente et al. 252; d. Valente et al. 350; e-g. Valente et al. 347; h-i. Miloski et al. 1). 
estaminódios ca. $1 \mathrm{~mm}$ compr., ovário obovoide, 2-carpelar, 2-locular, densamente pubescente, estilete bilobado, unido, estigma bilobado, ambos com 0,5-1 mm compr. Frutos esquizocárpicos com 1-2 mericarpos drupáceos, avermelhados, 0,6-1 $\times 0,5-0,7 \mathrm{~cm}$, obovoides, epicarpo membranáceo, glabro; endocarpo lenhoso; sementes 4-5 × 3-4 $\mathrm{mm}$, glabras, envolvidas por mesocarpo sulcoso; cotilédone externo curvo e interno biplicado.

Material examinado: Rio Preto, Serra da Caveira D'Anta, 25.II.2004, fr., K. Antunes et al. 58 (CESJ); 23.II.2004, fr., A. Valente et al. 350 (CESJ).

Material adicional: BRASIL. MINAS GERAIS: XI.1898, fl, Schwacke 13670 (RB). RIO DE JANEIRO: Arraial do Cabo, Ilha de Cabo Frio, Maramutá, Trilha para o farol, mata de encosta na vertente norte, Floresta Estacional Semidecídua, 14.IV.2000, fr., C. Farney \& J.C. Gomes 4069 (RB, RBR). SÃO PAULO: Guaratinguetá, Reserva Florestal da Escola de Especialistas da Aeronáutica-EEAR, mata de planalto, 8.XI.1995, fl., D.C. Cavalcanti 188 (HRCB, RBR); Campos do Jordão, Parque Estadual, região do paiol, sobre reflorestamento, III.1991, fr, M.J. Robim 687 (RBR, SPSF).

Allophylus semidentatus é uma espécie endêmica do Brasil. $\mathrm{Na}$ área de estudo foi coletada acima de $1.000 \mathrm{~m}$ de altitude, na floresta ombrófila densa. Esta espécie apresenta as seguintes características que a difere das demais do gênero: folíolos com margem serreada na metade distal, dentes com ápice acuminado e piloso; tirsos axilares, geralmente não ramificados, às vezes apresentando $1-2$ ramos basais curtos; flores com apêndice das pétalas bífidos, dividido na porção apical; nectários com quatro lobos nectaríferos e androginóforos presentes. Os frutos são usados como alimento por pássaros (Ferrucci et al. 2009). Allophylus semidentatus assemelhase vegetativamente a Allophylus edulis (A.St.Hil., A. Juss. \& Cambess.) Hieron ex Niederl., que apresenta as seguintes características: tirsos axilares, sempre não ramificados, flores com apêndice emarginado formando 2 linguetas inflexas, curtas e vilosas, disco nectarífero anelar e androginóforo ausente. Na Serra Negra foi coletada com frutos em fevereiro.

2. Cupania ludowigii Somner \& Ferrucci: Bot. J. Linn. Soc. 146(2): 217-221. 2004. Figs. 2b-d; 6a Nome popular: camboatá-vermelho.

Árvore 3-6 m alt., ramos subcilíndricos, levemente 5-costados; indumento de tricomas curtos, esbranquiçados a castanho-claros nos caules jovens, pecíolo, folíolos, raque e eixos da inflorescência. Folhas paripinadas, com 3-8 pares de folíolos, com folíolo terminal reduzido a um apículo; pecíolo 2,3-3,2 cm compr.; raque bicanaliculada; folíolos 5-6,5 × 1,8 cm, oblongos, obovados ou elípticos, alternos, cartáceos ou subcoriáceos, base aguda a arredondada, ápice retuso a emarginado, margem inteira, às vezes revoluta, face adaxial glabra, às vezes pubérula nas nervuras, face abaxial esparsamente adpresso-pubérula nas nervuras; domácias uni a plurifoveoladas. Tirsos axilares, paniculiformes, 3,5-8 cm compr., pubérulos ou pubescentes; cincinos 3-5-floros; brácteas triangular-ovadas, ca. $1 \mathrm{~mm}$ compr., pubescentes. Flores actinomorfas; cálice 5-mero, sépalas livres, ca. 1,5 mm compr., tomentosas; pétalas 5-meras, ca. 1,5 mm compr., erosas, com apêndice bipartido, bilobado no ápice, pouco mais longo que as pétalas, margem vilosa; disco nectarífero anelar, glabro; estames 3-4 mm compr., vilosos, pistilódio pubescente; estaminódios 1,5-2 mm compr.; ovário obovoide, 2-carpelar, ca. $2 \mathrm{~mm}$ compr., lateralmente achatado, densamente pubescente nos ângulos, estilete trilobado, unidos, 0,5-1 $\mathrm{mm}$ compr., estigma captado. Cápsula castanha, loculicida, 1,8-2,5 × 1,6-2,9 cm, obtriangular ou cordiforme, achatada lateralmente, coriácea, ápice apiculado, estípite 3-4 mm compr., epicarpo rugoso, glabro, septos do endocarpo pilosos; sementes 1-2, obovoides, 1,3-1,6 × 0,8 cm, glabras, arilo amarelo-alaranjado, eroso, ocupando 2/3 das sementes, com dois apêndices lineares na base; cotilédones planoconvexos.

Material examinado: Lima Duarte, Distrito de Monte Verde de Cima, RPPN Serra Negra, Estrada para Cachoeira do Véber, 16.VII.2009, fr., J.H.C. Ribeiro et al. 168 (CESJ); Rio Preto, Funil, Serra da Caveira D'Anta, 23.II.2004, fr, A. Valente et al. 350 (CESJ); 25.II.2004, fr, K Antunes et al. 58 (CESJ).

Material adicional: BRASIL. MINAS GERAIS: São João Nepomuceno, Serra dos Núcleos, 12.II.2003, fl., A. Valente et al. 252 (CESJ); Lima Duarte, I.1995, fl., V. C. de Almeida 146 (R, RBR).

Cupania ludowigii é endêmica do Brasil. $\mathrm{Na}$ Serra Negra C. ludowigii foi coletada em borda de floresta estacional semidecidual e em campo rupestre, entre 900 e $1.300 \mathrm{~m}$ de altitude. É muito confundida com C. emarginata Cambess. que ocorre nas restingas das regiões Sudeste e Nordeste do Brasil por apresentar semelhança na forma das folhas e frutos, porém, difere desta por possuir as seguintes características: folhas com 6 a 13 folíolos, os folíolos apresentam domácias uni a pluri-foveoladas na face abaxial, os apêndices das pétalas são levemente mais longos que as mesmas; 
frutos obtrangulares, achatados lateralmente; sementes com arilo amarelo-alaranjado que recobre 2/3 das mesmas e apresenta dois apêndices lineares na base. Na Serra Negra foi coletada com frutos em julho e novembro.

3. Cupania vernalis Cambess. in A. St.-Hil., A. Juss. \& Cambess., F1. Bras. Merid. 1: 387. 1828.

Figs. 2e-i; $6 \mathrm{~b}$

Cupania uraguensis Hook. \& Arn., Bot. misc. 3: 159. 1833.

Nomes populares: arco-de-barril, arco-depeneira, camboatá, camboatá-de-folhas grandes, camboatá-de-capoeira, cragoatã, guarantã, rabode-bugio.

Árvore 3-7 m alt., ramos 5-sulcados, indumento amarelado a castanho nos caules jovens, raque das folhas e eixos da inflorescência. Folhas paripinadas, com 5-7 pares de folíolos, com folíolo terminal reduzido a um apículo; pecíolo 4,5-6,8 cm compr; raque cilíndrica ou bicanaliculada; folíolos 4,5-10 × 2,5-4,5 cm, alternos, oblongoestreitos a oblongo-obovados, cartáceos, base aguda, atenuada ou assimétrica, ápice levemente obtuso ou retuso, margem denteado-serreada, face adaxial com tricomas apenas nas nervuras, face abaxial glabra ou pubérula; domácias pilosas ou em forma de pequena bolsa. Tirsos axilares e terminais, paniculiformes, às vezes não ramificados, 14-17 cm compr., tomentosos; cincinos 5-9 floros; brácteas triangulares, 1-3 mm compr., densamente tomentosas, bractéolas semelhantes às brácteas, ca. 0,2 mm compr. Flores actinomorfas; cálice 5-mero, sépalas livres, 1,7-2,5 mm compr., oblongas, ferrugíneo-pubescente-tomentosas; corola 5-mera, pétalas 1,7-3,8 mm compr., largo-obovadas, vilosas, com apêndice bipartido, ápice bilobado, menor que as pétalas, viloso; disco nectarífero anelar, glabro; estames 4-5,5 mm compr., pilosos, anteras amareladas a vináceas, pistilódio viloso; estaminódios 1,5-2 mm compr., ovário trígonoobovoide, 3-carpelar, denso ferrugíneo-viloso, estilete trilobado, lobos unidos, ca. $2 \mathrm{~mm}$ compr., ferrugíneo-hirsuto, estigma captado. Cápsula castanha, quando jovem amarelada, loculicida, 1,5-3 $\times 1,7 \mathrm{~cm}$, estípite $1-2 \mathrm{~mm}$ compr., trígono-obovoide ou trígono-piriforme, não achatada lateralmente, coriácea, epicarpo tuberculado-rugoso, denso amarelo-ocráceo-pubérulo, endocarpo ferrugíneoviloso; sementes $1-1,7 \times 0,6-1 \mathrm{~cm}$, glabras, arilo amarelo-alaranjado, ocupando $2 / 3$ da semente, arilo sem apêndices lineares na base da semente; cotilédones plano-convexos.
Material examinado: Rio Preto, Serra da Caveira D'Anta, 22.II.2004, fl., A. Valente et al. 347 (CESJ); Serra Negra, Vila do Funil, 30.VIII.2008, fr., J. Miloski et al. 1 (CESJ).

Material adicional: BRASIL. PARANÁ: Tamarana, fazenda do Virgílio, Três Minas, 18.V.2000, fl., O.C. Pavão et al. s.n. (FUEL, RBR 9453). RIO DE JANEIRO: Parque Nacional de Itatiaia, cabeceira da ponte do lago, 21.IV.2009, fr., G.V. Somner et al. 1301 (RBR).

Cupania vernalis não é endêmica do Brasil, ocorre também em outros países da América do Sul como Bolívia, Paraguai oriental, Argentina e Uruguai. Na Serra Negra esta espécie foi encontrada tanto em borda de floresta estacional semidecidual e floresta ombrófila densa, como em região de transição com campo rupestre, entre 900 e $1.000 \mathrm{~m}$ de altitude. Destaca-se da outra espécie estudada, C. ludowigii por apresentar as seguintes características: indumento amarelado a castanho nos caules jovens, raque das folhas e eixos da inflorescência; folíolos com margem denteado-serreada; flores com pétalas portando apêndice bipartido, bilobado, menor que a pétala; cápsulas com epicarpo tuberculado-rugoso, denso amarelo-ocráceo-pubérulo. Foi coletada com flores em fevereiro e com frutos em agosto.

4. Matayba juglandifolia Radlk. in Sitzungsber. Math.-Phys. Cl. Königl. Bayer. Akad. Wiss. München 9: 6351879.

Fig. 3a-d

Nome popular: Camboatá-amarelo.

Árvore 3-15 m alt., ramos cilíndricos, glabros, jovens com tricomas esbranquiçados ou amarelados, curtos, adpressos. Folhas paripinadas, com 3-6 pares de folíolos, com folíolo terminal reduzido a um apículo; pecíolo 2,8-7 cm compr.; raque subcilíndrica ou bicanaliculada; folíolos 4,5-15 × 1,9-6,5 cm, subopostos ou alternos, oblongos ou obovados, cartáceos, quando secos verde-amarelados na face adaxial, glabros, base aguda, atenuada e assimétrica, ápice retuso a arredondado ou emarginado; margem inteira, revoluta; nervura principal impressa, secundárias retas ou curvas, não proeminentes na face adaxial, na face abaxial nervura principal proeminente; às vezes domácias em bolsas. Tirsos axilares, paniculiformes, 4-19,5 cm compr., pubescentes; cincinos 3-6-floros; brácteas triangulares, ca. 2 $\mathrm{mm}$ compr., pubescentes. Flores actinomorfas; cálice 5-mero, sépalas conatas, 1,5-2 mm compr., ovadas, pubescentes, corola 4-mera, pétalas 1,5-2 mm compr., obovadas, subséssil, com apêndice bipartido, ápice bilobado com lobos irregulares, de tamanho semelhante ou menor que a pétala, 

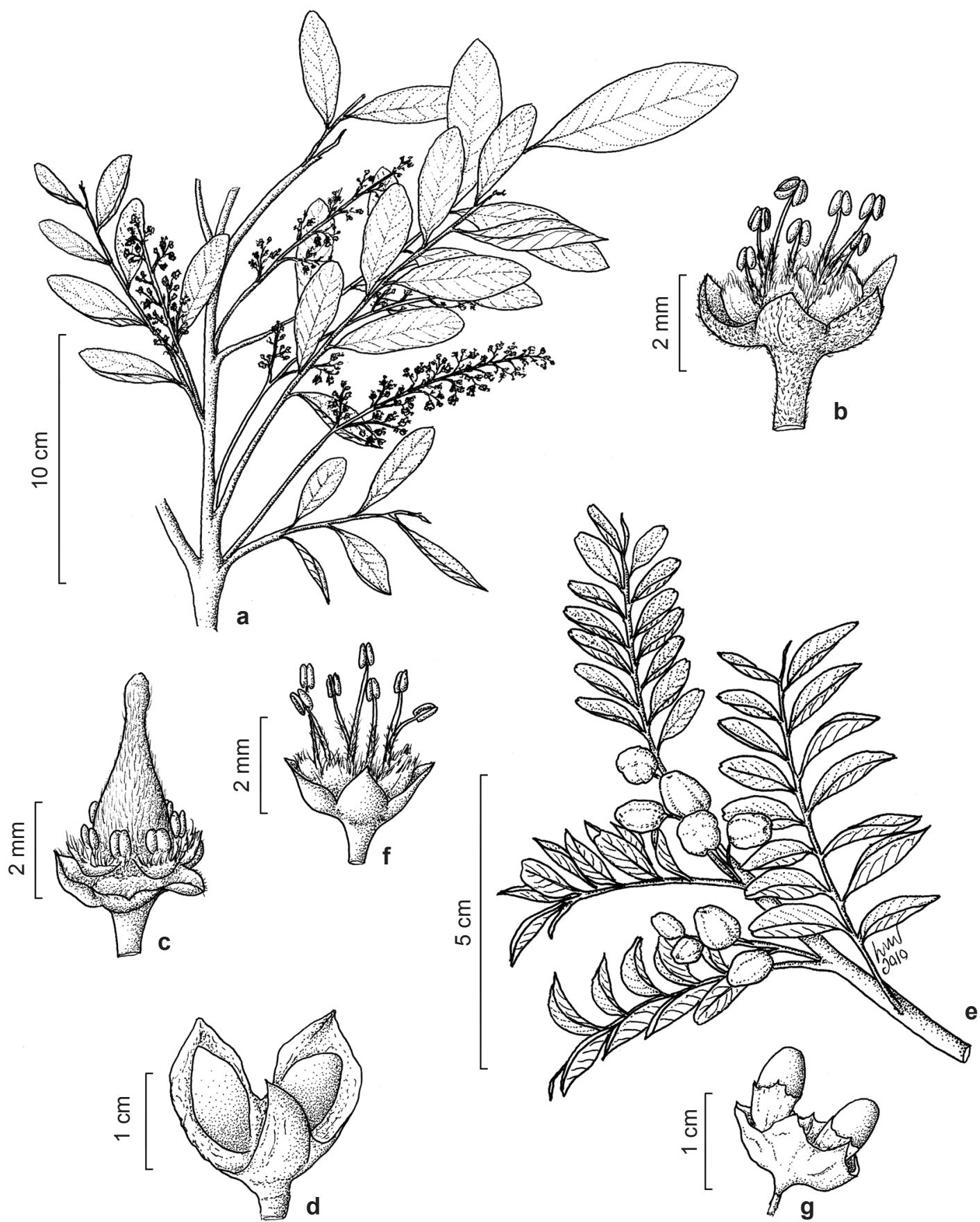

Figura 3 - a-d. Matayba juglandifolia - a. ramo florífero; b. flor masculina; c. flor feminina; d, cápsula loculicida aberta. e-g. Matayba marginata - e. ramo frutífero; f. flor masculina; g. cápsula loculicida aberta mostrando as sementes com arilo. (a-c. Miloski et al. 2; d. Souza et al. 281; e, g. Salimena et al. 3591; f. Miloski et al. 3).

Figure 3 - a-d. Matayba juglandifolia - a. branch with flowers; b. male flower; c. female flower; d. open loculicidal capsule. e-g. Matayba marginata - e. branch with fruits; f. male flower; g. open loculicidal capsule showing the seeds with aril. (a-c. Miloski et al. 2; d. Souza et al. 281; e, g. Salimena et al. 3591; f. Miloski et al. 3). 
densamente viloso; disco nectarífero anelar, glabro; estames 8, 3-5 mm compr., pubescentes, anteras amareladas, pilosas, pistilódio viloso; estaminódios 1-2 mm compr.; ovário trilobadoelipsoide-globoso, 3-carpelar, densamente amarelo-pubescente, estilete levemente trilobado, unidos, ca. $3 \mathrm{~mm}$ compr., estigma captado. Cápsula avermelhada ou castanha, loculicida, 1,2-2,2 $\times$ 1,2-2 cm, obovoide-globosa, coriácea, subséssil, verrucosa, quando jovem epicarpo pubescente, maduro glabro, endocarpo tomentoso; sementes 0,7-1 × 0,5-0,7 cm, obovoides, glabras, arilo branco a amarelado, recobrindo totalmente as sementes; cotilédone externo curvo e interno biplicado.

Material selecionado: Rio Preto, Serra Negra, 2007, fr., A.S.M. Valente \& P.O. Garcia (CESJ 49344); Cambuí, 13.X.2007, fl. e fr., F. S. Souza et al. 281 (CESJ); Vila do Funil, 30.VIII.2008, fl., J. Miloski et al. 2 (CESJ).

Matayba juglandifolia é uma espécie endêmica do Brasil. Na Serra Negra $M$.juglandifolia foi encontrada no interior de floresta ombrófila densa a ca. $1.000 \mathrm{~m}$ de altitude. Este táxon difere de $M$. marginata por apresentar folíolos grandes (4,5-15 × 1,9-6,5 cm), cápsulas verrucosas e as sementes cobertas totalmente por arilo branco a amarelado. Segundo Reitz (1980), as pombas procuram os frutos desta espécie para alimentação. Foi coletada com flores de agosto a outubro e com frutos em outubro.

5. Matayba marginata Radlk. in Sitzungsber. Math.-Phys. Cl. Königl. Bayer. Akad. Wiss. München 9: 634. 1879. Figs. 3e-g; 6c

Arvoreta ca. $3 \mathrm{~m}$ alt.; ramos jovens, raque foliar e eixo da inflorescência pubescentes, com tricomas amarelados; ramos cilíndricos, subglabros a pubescentes. Folhas paripinadas, 5-7 pares de folíolos, dispostos geralmente no ápice do ramos, com folíolo terminal reduzido a um apículo; pecíolo 0,6-1,5 cm compr.; raque marginada ou subalada; folíolos $2-3 \times 0,8 \mathrm{~cm}$, subopostos a alternos, oblongos a elíptico-oblongos, cartáceos, quando secos castanho-claros ou verde-escuros na face adaxial, base levemente atenuada ou assimétrica, ápice arredondado a retuso, margem inteira, revoluta, face adaxial lustrosa, proeminente e pubérula apenas na nervura principal, nervuras secundárias curvas, face abaxial pubérula; domácias foveoladas ou urceoladas. Tirsos axilares, não ramificadas ou paniculiformes, 5-7 cm compr., pubérulos; brácteas triangulares, ca. 1,5 mm compr., pubescentes. Flores actinomorfas; cálice 5-mero, sépalas ovadas, ápice agudo, conatas, ca. $1 \mathrm{~mm}$ compr., ciliadas; corola 4-mera, pétalas obovadas, 1-1,2 $\mathrm{mm}$ compr., ciliadas, apêndice bipartido até a base da unha, lobos obovados, densamente vilosos, do mesmo tamanho ou maior que as pétalas; nectário em forma de disco anelar, glabro; estames 8, 3-3,5 mm compr., pubescentes; anteras glabras; estaminódios 1,3-1,5 mm compr., ovário trilobado-ovoide, 3-carpelar, densamente amarelo-adpresso-pubescente, estilete trilobado, ca. $1 \mathrm{~mm}$ compr., lobos unidos, estigma trilobado, ca. 0,3 mm compr. Cápsula avermelhada, loculicida, levemente trilobado ou bilobado-ovoide ou globoso, 1-2 × 1-1,4 cm, coriácea, subséssil, rugosa, epicarpo pubérulo, endocarpo branco a ferrugíneo-viloso; sementes 1-3, elipsoides, ca. $8 \times 6 \mathrm{~mm}$ glabras, com arilo amarelado, cobrindo 2/3 da semente; embrião plano-convexo.

Material selecionado: Rio Preto, Serra da Caveira D'Anta, Fazenda Tiririca, 15.XI.2003, fl. e fr., F.R. Salimena et al. 1144 (CESJ); Serra do Funil, 11.IX.2004, fr., C.N. Matozinhos et al. 64 (CESJ, SPFR); RPPN São Lourenço do Funil, 19.VII.2013, fr., F.R.G. Salimena et al. 3591 (CESJ); Serra Negra, Fazenda Santa Luzia, 31.VI.2007, fl. e fr., F.R. Salimena et al. 2472 (CESJ); Serrinha, Sítio do Degredo, 21.VIII.2009, fl., J.A. Oliveira et al. 85 (CESJ); Trilha para o Burro de Ouro, 18.V.2006, fl., N.L. Abreu et al. 87 (CESJ); Gruta do Funil, 31.VIII.2008, fl., J. Miloski et al. 3 (CESJ); Trilha para a cachoeira da Água Amarela, 13.VI.2012, fl., J.H.C. Ribeiro et al. 238 (CESJ); Lima Duarte, Serra Negra, RPPN Serra Negra, 25.X.2008, fl., J.H.C. Ribeiro et al. 22 (CESJ).

Matayba marginata é endêmica do Brasil. $\mathrm{Na}$ Serra Negra $M$. marginata foi registrada apenas uma vez em borda de floresta sendo mais frequente nos campos rupestres, em altitudes entre 1.000 e ca. $1.600 \mathrm{~m}$, formando grande população. Esta espécie se destaca por apresentar folíolos geralmente no ápice dos ramos, medindo $(2-3 \times 0,8 \mathrm{~cm})$, e a raque é marginada ou subalada. Os frutos são cápsulas avermelhadas, e suas sementes apresentam arilo amarelado que cobre 2/3 das mesmas. Foi coletada com flores de maio a dezembro e com frutos de junho a dezembro.

6. Paullinia carpopoda Cambess. in A. St.-Hil., Fl. Bras. Merid. 1: 376, t. 78. 1828. Figs. 4a-c; 6d Nome popular: cipó-uva.

Trepadeira lenhosa lactescente, caule cilíndrico, estriado ou levemente costado, castanho, pubescente, em seção transversal com apenas um cilindro vascular. Folhas imparipinadas, 11-folioladas ou 13-folioladas, folíolos basais 
trifoliolulados; estípulas lanceoladas; pecíolo cilíndrico, 3,2-5,7 cm compr.; raque foliar alada; folíolos 3,5-8 × 1,5-2,5 cm, lanceolados ou elípticos, cartáceos ou subcoriáceos, base cuneada, aguda, atenuada ou assimétrica; ápice agudo ou acuminado, mucronado, margem inteira, revoluta, face adaxial glabra exceto na nervura principal, face abaxial glabra a pubescente; domácias pilosas. Tirsos racemiformes, pedúnculo 1,3-2 cm compr., raque $5,5-11,5 \mathrm{~cm}$ compr., pubescentes, cincinos 3-6-floros, brácteas triangulares, 5-6 mm compr., pubescentes. Flores zigomorfas; cálice 4-mero, sépalas livres, ovadas, duas externas $1-2,5 \mathrm{~mm}$ compr., densamente adpresso-pubescentes, duas internas 3-5 $\mathrm{mm}$ compr., obovadas, incanodenso-pubescente; corola 4-mera, pétalas 2,5-4 $\mathrm{mm}$ compr., obovadas, ápice dos apêndices das pétalas posteriores com crista emarginada; lobos nectaríferos 4, posteriores suborbiculares, laterais reduzidos; androginóforo pubérulo; estames 2-3 mm compr., velutinos, pistilódio glabro; estaminódios 2-3 mm compr., ovário elipsoide-globoso, 3-carpelar, glabro, estilete ca. $0,5 \mathrm{~mm}$ compr., pubescente, estigma ca. $0,5 \mathrm{~mm}$ compr. Cápsula avermelhada, septífraga, 3-3,7 × 1,5-2 cm, porção globosa 6-costada, apiculada, crustácea, 1 -seminada, estípite $0,9-1,7 \mathrm{~cm}$ compr., epicarpo e endocarpo glabros; sementes subglobosas ou elipsoides, 1,2-1,5 ×0,9-1,6 cm, glabras, sarcotesta cobrindo totalmente ou quase toda a semente, cotilédones subretos.

Material selecionado: Rio Preto, Serra Negra, 13.X.2007, fr., S.A. Roman et al. 23 (CESJ); Estrada para Lima Duarte, 19.IV.2009, fl., L. Menini Neto et al. 670 (CESJ); Vila do Funil, 30.VIII.2008, fr., J. Miloski et al. 5 (CESJ, SPRF); Gruta do Funil, 23.X.1988, fr, R.C.Oliveira 23480 (CESJ); Funil, Fazenda Tiririca, 24.IV.2004, fl., fr, K. Antunes et al. 105 (CESJ); Trilha da ponte em direção ao Serrote de São Gabriel, 2.VI.2006, fl., F.R.G. Salimena et al. 1370 (CESJ); Serra do Funil, 20.VIII.2004, fr., C.N. Matozinhos et al. 32 (CESJ); Olaria, Estrada do Rio Preto, 10.XI.2003, fr., F.R.G. Salimena et al. 1117 (CESJ); Lima Duarte, Distrito de Monte Verde de Cima, RPPN Serra Negra, 30.V.2009, fl. e fr., F.S. Souza \& J.H.C. Ribeiro 678 (CESJ).
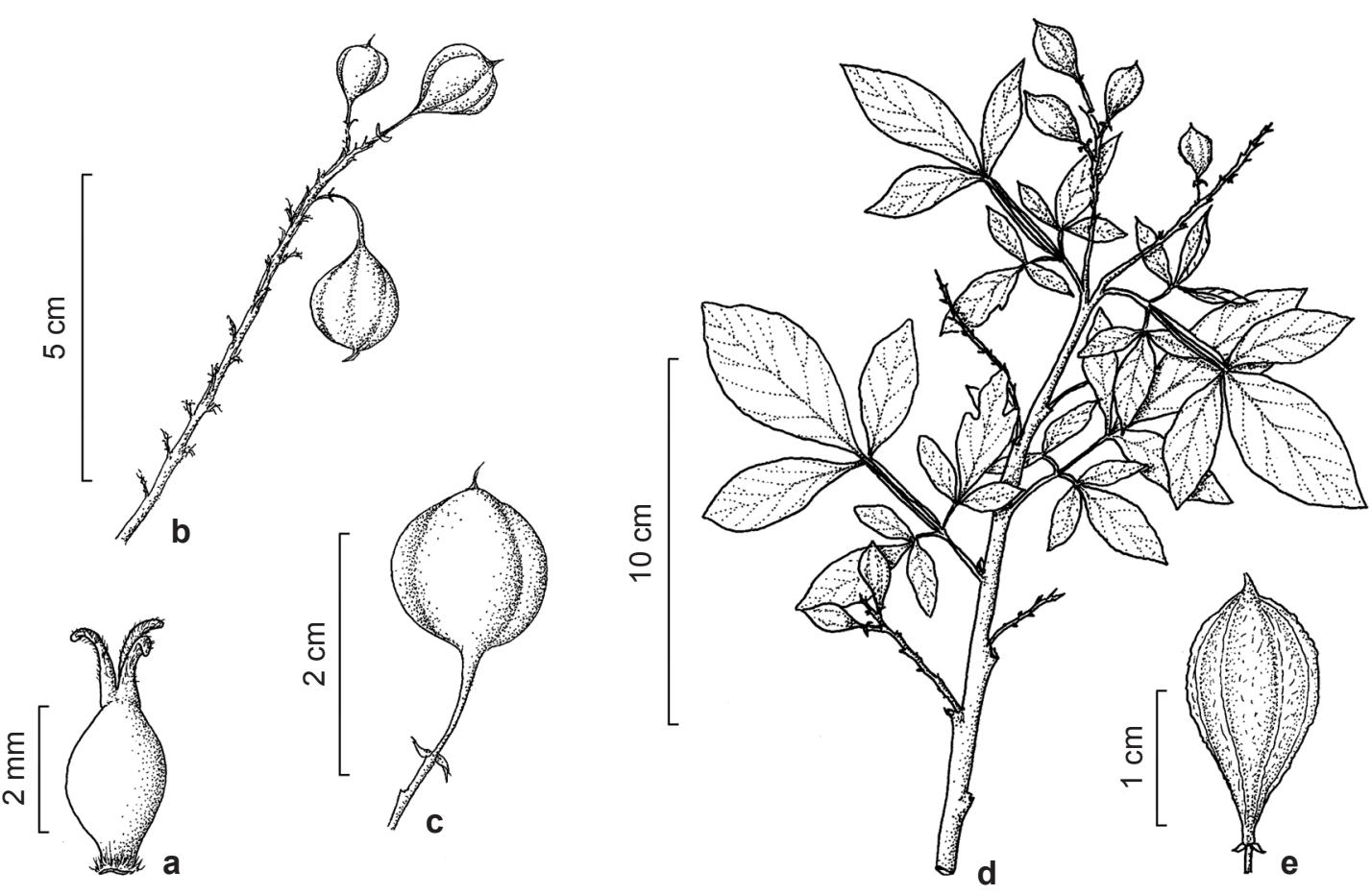

Figura 4 - a-c. Paullinia carpopoda - a. pistilo; b. infrutescência; c. detalhe da cápsula. d-e. Paullinia trigonia - d. ramo frutífero; e. detalhe da cápsula septífraga. (a. Menini Neto et al. 670; b-c. Souza \& Ribeiro 678; d-e. Matozinhos et al. 58).

Figure 4 - a-c. Paullinia carpopoda - a. pistil; b. infrutescence; c. detail of capsule. d-e. Paullinia trigonia - d. branch with fruits; e. detail of septifragal capsule. (a. Menini Neto et al. 670; b-c. Souza \& Ribeiro 678; d-e. Matozinhos et al. 58). 
Paullinia carpopoda é uma espécie endêmica do Brasil. Na Serra Negra foi encontrada em borda de floresta ciliar e campo rupestre entre 900 e $1.000 \mathrm{~m}$ de altitude. É uma espécie melífera (Pirani \& Cortopassi-Laurino 1993). Difere de Paullinia trigonia por apresentar caule castanho, liso, folíolos lanceolados ou elípticos, com margem inteira e revoluta. As cápsulas não são aladas, apresentam uma porção globosa 6-costada, apiculada, uniseminada e estípite variando de 0,9 a $2 \mathrm{~cm}$ compr. Foi coletada com flores abril a junho e com frutos de abril a novembro.

7. Paullinia trigonia Vell., Fl. flum. 1: 159. 1825; Icon. 30. 1829.

Figs. 4d-e; 6e

Nomes populares: Cipó-timbó, timbó-decipó, timbó-aitica, timbó, tingui-cipó.

Trepadeira lenhosa lactescente, com tricomas esbranquiçados ou castanhos na raque, pecíolo, estípulas e eixos da inflorescência; caule castanhoavermelhado, estriado, densamente hirtelo ou glabrescente, em seção transversal com apenas um cilindro vascular. Folhas geralmente biternadas, ou imparipinadas 11-folioladas ou 13-folioladas, folíolos basais trifoliolulados; estípulas ovadas; pecíolo 2,5-4,7 cm compr.; raque marginada ou alada; folíolos 2,6-6 × 1,2-2,5 cm, ovadoromboidais a elíptico-lanceolados, subcoriáceos, base cuneada, aguda ou atenuada, ápice agudo ou obtuso, margem denteado-serreada, revoluta, pubescentes na nervura principal em ambas as faces ou pubescente na face abaxial e apenas nas nervuras da face adaxial; domácias pilosas. Tirsos racemiformes, pedúnculo $0,6-1,4 \mathrm{~cm}$ compr., raque 1,5-3,7 cm compr., pubescentes; cincinos 4-6-floros; brácteas triangulares, ca. 8 mm compr., pubescentes, bractéolas semelhantes as brácteas, $4-5 \mathrm{~mm}$ compr. Flores zigomorfas; cálice 4-mero, sépalas livres, duas externas obovadas, 1-2,5 $\mathrm{mm}$ compr., pubérulas, duas internas obovadas, pubescentes; corola 4-mera, pétalas obovadas, ca. $2 \mathrm{~mm}$ compr., ápice dos apêndices das pétalas posteriores com crista erosa; lobos nectaríferos 4 , posteriores ovoides, laterais menores; androginóforo piloso; estames ca. 1,2 $\mathrm{mm}$ compr., pubescentes, estaminódios ca. $1 \mathrm{~mm}$ compr., ovário trígono-ovoide, 3-carpelar, pubérulo nos ângulos, estilete subséssil, estigma trífido, ca. 0,2 mm compr. Cápsula avermelhada, septífraga, trialada ou tricarenada, trígono-elipsoide ou trígono-obovoide, $0,9-2 \times 0,5-1,3 \mathrm{~cm}$, subcoriácea, estípite 1-5 mm, 1-3 seminadas, epicarpo glabro, endocarpo tomentoso na margem das valvas; sementes trígono-elipsoides ou trígono-obovoides, 8-9 × 6-7 mm, glabras, sarcotesta cobrindo 1/2-2/3 da semente, cotilédone externo curvo e interno biplicado.

Material selecionado: Rio Preto, Serra Negra, Trilha para Cachoeira da Água Amarela, s.d., fl. e fr, N.L. Abreu et al. 159 (CESJ); Mata do Cambuí, IX.2011, fr., R.J.V. Alves \& N.L. Abreu 8762 (CESJ). Boqueirão, divisa com Santa Bárbara do Monte Verde, fl, 16.II.2007, F.R.G. Salimena \& P.H. Nobre 2430 (CESJ); Serra da Caveira D'Anta, fazenda da Tiririca, fl, 25.II.2004, K. Antunes et al. 55 (CESJ); Serra do Funil, Trilha para o Ninho da Égua, 21.VIII.2004, fr., C.N. Matozinhos et al. 58 (CESJ, SPRF); Vila do Funil, RPPN São Lourenço do Funil e RPPN Serrinha, 15.VIII.2013, fr., F.R.G. Salimena et al. 3600 (CESJ).

Material adicional: BRASIL. MINAS GERAIS: Novo Cruzeiro, Estrada Palmeiras para a Fazenda Araras, $\mathrm{S}$ $17^{\circ} 38^{\prime} 42^{\prime \prime}, \mathrm{W} 41^{\circ} 59^{\prime} 37.7^{\prime \prime}$, alt. $810 \mathrm{~m}$, 2.XII.2004, fl., J.R. Stehmann et al. 3681 (BHCB, RBR).

Paullinia trigonia é uma espécie endêmica do Brasil. Na Serra Negra P. trigonia é encontrada na borda e no interior de floresta ombrófila densa e floresta estacional semidecidual, além de campo rupestre entre 900 e ca. $1.100 \mathrm{~m}$ de altitude. Destaca-se das demais espécies por apresentar caule castanho-avermelhado, estriado. Os folíolos são ovado-romboidais a elíptico-lanceolados, com margem denteado-serreada. Os frutos são cápsulas trialadas ou tricarenadas, trígono-elipsoide ou trígono-obovoide, com 1 a 3 sementes, e com estípite variando de 1 a $5 \mathrm{~mm}$ compr. Foi coletada com frutos de agosto a setembro.

8. Serjania deflexa Gardner, London J. Bot. 2: 337. 1843.

Fig. 5a-e

Trepadeira lenhosa; caule, pecíolo, raque da folha e eixo da inflorescência ferrugíneo, densosetoso-hirsutos e com tricomas glandulares; caule 5 -sulcados, em seção transversal composto por um cilindro vascular central pequeno e 5 cilindros vasculares radiais. Folhas biternadas, estípulas subuladas, 1-2 mm compr., pecíolo canaliculado, ca. 2 cm compr.; raque bicanaliculada; folíolos 1,5-4,2 $\times$ 0,5-2 cm, ovados, elípticos ou lanceolados, cartáceos, quando secos a face adaxial castanho-escura e a face abaxial castanho-clara; base atenuada, obtusa e ou assimétrica, ápice acuminado, mucronado, margem inteira ou com 1-2 dentes, ciliada, com tricomas setosos; face adaxial setosa e com tricomas glandulares, face abaxial com tricomas lanuginosos; domácias ausentes. Tirsos racemiformes, congestos, pedúnculo 2,5-9 cm compr., raque 3-11 cm compr.; cincinos 4-7-floros, brácteas linear-subuladas, ca. $1 \mathrm{~mm}$ compr., setosas, com tricomas glandulares. 




Figura 5 - a-e. Serjania deflexa - a. ramo florífero; b. detalhe do indumento do caule; c. pistilo; d. detalhe do estigma; e. mericarpos samaroides. f-i. Serjania elegans - f. ramo floríferos; g. corte transversal do caule; h. pistilo; i. mericarpos samaroides. j-k. Serjania laxiflora - j. pistilo; k. mericarpos samaroides. 1-n. Serjania multiflora - 1. corte transversal do caule; m. flor masculina; n. mericarpos samaroides. (a-d. Antunes et al. 133; e. Somner et al. 1453; f-i. Salimena \& Nobre 2456; j-k. Matozinhos et al. 195; 1-n. Miloski et al. 6).

Figure 5 - a-e. Serjania deflexa - a. branch with flower; b. detail of stem indument; c. pistil; d. detail of stigma; e. samaroid mericarps. f-i. Serjania elegans - f. branch with flowers; g. cross cut of stem; h. pistil; i. samaroid mericarps. j-k. Serjania laxiflora - j. pistil; k. samaroid mericarps. 1-n. Serjania multiflora - 1. cross cut of stem; m. male flower; n. samaroid mericarps. (a-d. Antunes et al. 133; e. Somner et al. 1453; f-i. Salimena \& Nobre 2456; j-k. Matozinhos et al. 195; 1-n. Miloski et al. 6). 
Flores zigomorfas; sépalas 5, livres, ovadas, duas externas ca. $3 \mathrm{~mm}$ compr. e três internas 3,5-5 mm compr., hirsuto-setosas e com tricomas glandulares; pétalas 4, obovadas, 4,5-6 mm compr., longo unguiculadas (ca. 1,5 mm compr.), com tricomas setosos, ápice dos apêndices das pétalas posteriores com crista erosa; lobos nectaríferos 4 , posteriores suborbiculares, lateral reduzidos; androginóforo pubérulo; estames 3-4,5 mm compr., vilosos; estaminódios 2,5-3 mm compr., ovário trígonoobovoide, 3-carpelar, densamente hirsuto-setoso, com tricomas glandulares, avermelhados, longos, estilete ca. $1 \mathrm{~mm}$ compr., estigma trífido, 0,7-1 mm compr. Mericarpos samaroides castanhos, cartáceos, 3-3,4 $\times 1,8-2,5 \mathrm{~cm}$, subretangular ou subcordado, porção seminífera do mericarpo achatada lateralmente, epicarpo com indumento densamente hirsuto-setoso, mais longos na porção seminífera do que nas alas e com tricomas glandulares; em nível dos lóculos 1,6-2 cm larg., crista dorsal 2-2,5 mm larg., revoluta, alas mais ou menos retas; endocarpo ferrugíneo-viloso; sementes lenticulares, 4-6 × 3-5 $\mathrm{mm}$, glabras; cotilédone externo curvo e interno biplicado.

Material examinado: Rio Preto, Serra Negra, Estrada do Vilarejo do Funil, 21.V.2004, fl., K. Antunes et al. 133 (CESJ).

Material adicional: BRASIL: MINAS GERAIS: Bicas, 13.VI.1970, fl, P.L.K. \& Urbano 8731 (CESJ, RBR). RIO DE JANEIRO: Itatiaia, Parque Nacional de Itatiaia, borda da estrada para o hotel Donati, S 22 26'53,2”, W 044³6'17,6”, 27.VIII.2009, fr., G.V. Somner et al. 1453 (RBR).

Serjania deflexa é uma espécie endêmica do Brasil. Na Serra Negra S. deflexa foi encontrada na borda de floresta estacional semidecidual a ca. $900 \mathrm{~m}$ de altitude. Destaca-se por apresentar caule densamente ferrugíneo-setoso-hirsuto, em seção transversal composto por um cilindro vascular central pequeno e 5 cilindros vasculares radiais. Os folíolos com face adaxial setosa e com tricomas glandulares, face abaxial com tricomas lanuginosos. Os frutos possuem a porção seminífera dos mericarpos samaroides achatada lateralmente, coberta por tricomas setosos, e as sementes são lenticulares. Na Serra Negra foi coletada com flores em maio.

\section{Serjania elegans Cambess., in A. St.-Hil., Fl.} Bras. Merid. 1: 358. 1828. Figs 5f-i; $6 \mathrm{f}$

Nome popular: Timbó-mata-peixe.

Trepadeira lenhosa; caule 5-costado, pubérulo e com tricomas glandulares, em seção transversal com um cilindro central pequeno e cinco cilindros vasculares radiais. Folhas biternadas, estípulas subulado-lanceoladas; pecíolo canaliculado, 1,5-4,5 cm compr.; raque canaliculada; folíolos 2,5-10 $\times 1-3,5 \mathrm{~cm}$, ovado-lanceolados ou lanceolados, cartáceos; base atenuado, obtuso ou assimétrica; ápice agudo ou acuminado, mucronado; margem inteira ou com 1 ou 2 dentes obtusos, face adaxial e abaxial pubescente, com tricomas glandulares; domácias pilosas. Tirsos racemiformes laxifloros, pedúnculo 6-14 cm compr., raque 4-19,5 cm compr.; cincinos 4-5-floros; brácteas triangulares, 1-1,2 mm compr., ápice cuspidato, bractéolas semelhantes, ca. 0,5 mm compr., pubescentes e com tricomas glandulares. Flores zigomorfas; cálice 5-mero, sépalas róseas, livres, membranáceas, pubérulas, margem com tricomas glandulares, duas externas ovadas, 3,5-4 mm compr., subcartáceas, três internas ovadas ou obovadas, 4,5-6 mm compr., pétalas 4, 6,5-7 mm compr., obovadas, membranáceas, ápice dos apêndices das pétalas posteriores com crista emarginada ou erosa; lobos nectaríferos 4, posteriores ovoides, laterais reduzidos; androginóforo glabro; estames 3,5-5 mm, setoso-vilosos; estaminódios 2,5-3 mm compr., ovário trígono-obovoide, 3-carpelar, hirsuto-setoso, com tricomas glandulares, estilete 1,5-2 mm compr., pubescente em 1/3 basal, estigma trífido, 0,5-0,7 mm compr. Mericarpos samaroides róseos, ovadocordados ou subretangulares, 2,5-3 × 1,7-2 cm, cartáceos, porção seminífera do mericarpo achatado lateralmente, epicarpo da porção seminífera e alas pubérulos e com tricomas glandulares, crista 2-3 $\mathrm{mm}$ larg., endocarpo com raros tricomas longos; sementes lenticulares, 5-7 × 3-5 mm, glabras, cotilédone externo curvo e interno biplicado.

Material selecionado: Rio Preto, Serra Negra, próximo ao Cânion, s.d., fl. e fr., C.N. Matozinhos et al. 326 (CESJ); Fazenda Santa Luzia, 31.VI.2007, fl. e fr., F.R.G. Salimena \& P.H. Nobre 2465 (CESJ); Trilha para o Ninho da Égua, 2.V.2009, fl, D. Monteiro et al. 537 (CESJ); Fazenda Tiririca, 26.VI.2008, fl. e fr., F. S. Souza \& O.J. Bastos 524 (CESJ); Trilha da cachoeira da Água Amarela, 26.III.2013, fl., K. Antunes \& R. J. V. Alves 405 (CESJ); Mata da Dona Luzia, 12.X.2007, fl., S.A. Roman et al. 20 (CESJ); Serra do Funil, fr, 11.IX.2004, C.N. Matozinhos et al. 90 (CESJ); próximo à Gruta do Funil, 1.VI.2006, fl., P.L. Vianna et al. 2157 (CESJ).

Material adicional: BRASIL. RIO DE JANEIRO: Itatiaia, Parque Nacional, BR 485, fim da Trilha Barbosa Rodriguez, ao lado do rio, 21.V.2010, fl., G.V. Somner et al. 1518 (RBR).

Serjania elegans é uma espécie endêmica do Brasil. Na Serra Negra S. elegans é muito frequente, sendo encontrada em campo rupestre, na borda de floresta ombrófila densa e também no 

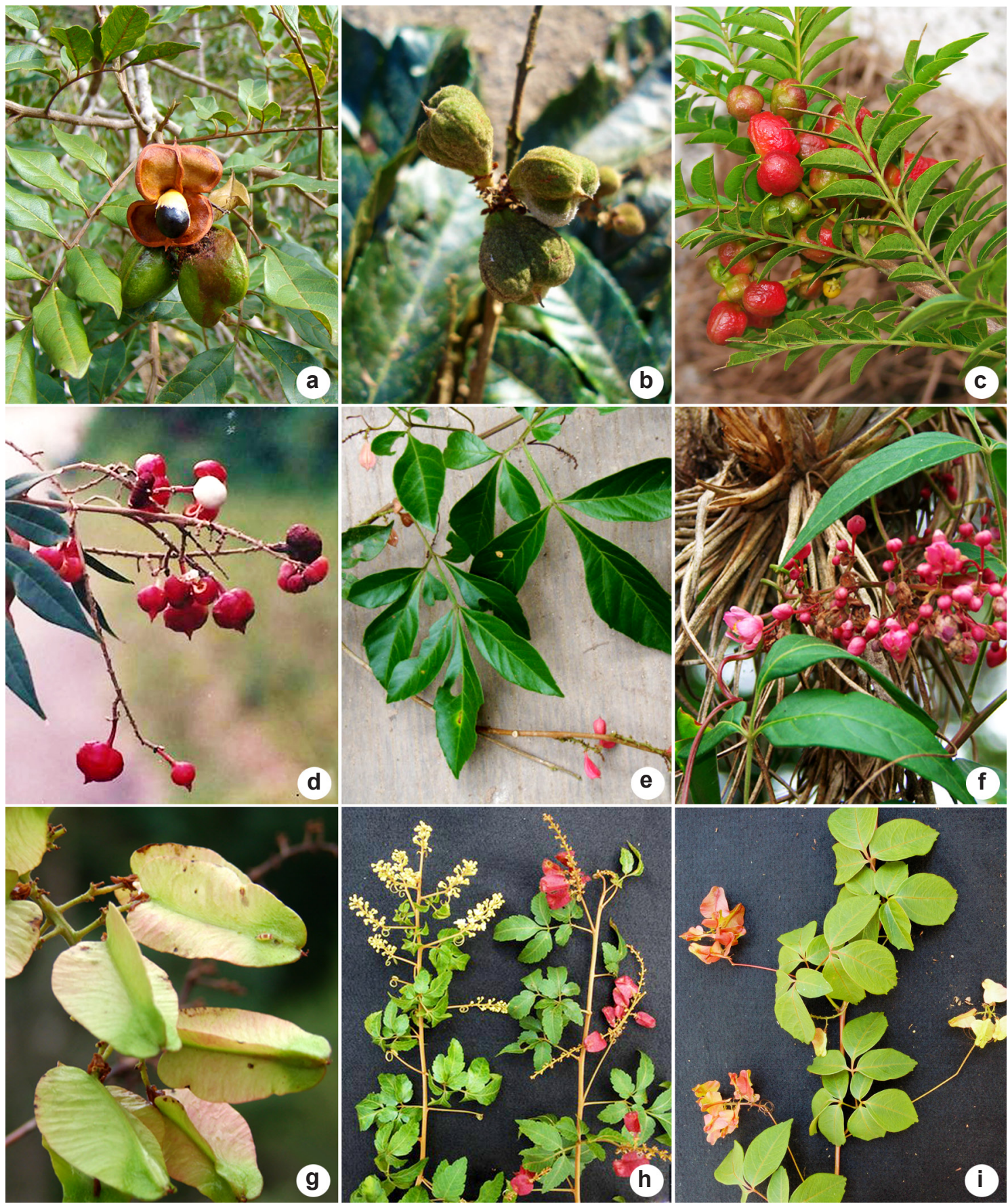

Figura 6 - a. Cupania ludowigii - ramo frutífero e detalhe do fruto aberto. b. Cupania vernalis - cápsulas jovens. c. Matayba marginata - ramos frutíferos. d. Paullinia carpopoda - ramos frutíferos e detalhe das cápsulas. e. Paullinia trigonia - ramos frutíferos - f. Serjania elegans - ramo florífero. g. Serjania laruotteana - mericarpos samaroides jovens. h. Serjania fuscifolia - ramos florífero e frutífero. i. Serjania reticulata - ramos frutíferos. (Fotos: a. Filipe S. Souza; b, d, e. Genise V. Somner; c, f, g. Luiz Menini Neto; h, i. Thiago Flores).

Figure 6 - a. Cupania ludowigii - branch with fruits and detail of open fruit. b. Cupania vernalis - immature capsules. c. Matayba marginata - branches with fruits. d. Paullinia caropopoda - branch with fruits and detail of the capsules. e. Paullinia trigonia - branch with fruits. f. Serjania elegans - branch with flowers. g. Serjania laruotteana - immature samaroid mericarps. h. Serjania fuscifolia branches with flowers and fruits. i. Serjania reticulata - branch with fruits. (Photos: a. Filipe S. Souza; b, d, e. Genise V. Somner; c, f, g. Luiz Menini Neto; h, i. Thiago Flores). 
ecótono entre estas duas formações, entre 900 e $1.000 \mathrm{~m}$ de altitude. Esta espécie destaca-se por apresentar caule em seção transversal composta por um cilindro central pequeno e cinco cilindros vasculares radiais; folíolos ovado-lanceolados ou lanceolados, com margem inteira ou com 1 ou 2 dentes obtusos. Suas flores possuem corola rósea, que juntamente com $S$. velutina Radlk., espécie do cerrado, diferem das demais espécies de Serjania que apresentam cor branca ou branco-amarelada. Os frutos são mericarpos samaroides ovadocordados ou subretangulares, róseos, pubérulos e com tricomas glandulares, a porção seminífera do mericarpo é achatada lateralmente. As sementes são lenticulares. Na Serra Negra foi coletada com flores e frutos de abril a junho.

10. Serjania fuscifolia Radlk., Consp. sect. sp. Serjan.: 10. 1874.

Nome popular: cipó-timbó.

Trepadeira lenhosa lactescente, pubescente; caule 8-10-costado, em seção transversal composto por um cilindro vascular central e 8 cilindros vasculares periféricos do mesmo tamanho que o central. Folhas biternadas, estípulas triangulares, ca. 0,2 cm compr., persistentes; pecíolo canaliculado, 0,8-6 cm compr., raque bicanaliculada; folíolos $0,8-4,2$ $\times 0,5-1,8 \mathrm{~cm}$, subromboidais, ovado, ovadolanceolados ou elípticos, cartáceos; base cuneada, atenuada, obtusa ou assimétrica; ápice agudo, obtuso ou acuminado, mucronado; margem denteado-serreada, dentes arredondados; face adaxial brilhantes, castanho-escura, velutina, e nas nervuras densamente tomentosas, com tricomas branco-amarelados, face abaxial opaca, castanho mais clara, velutina e com tricomas glandulares; domácias pilosas. Tirsos racemiformes, pedúnculo 2-10 cm compr., raque 3,5-16,5 cm compr., tomentosos; cincinos 4-9-floros; brácteas subuladas, 1,2-1,5 $\mathrm{mm}$ compr., velutinotomentosas, bractéolas semelhantes ás brácteas, 0,2-0,7 mm compr. Flores zigomorfas; cálice 5-mero, sépalas livres, duas externas ovadas, ca. $2 \mathrm{~mm}$ compr., velutino-tomentosas, três internas ovadas, ca. $3 \mathrm{~mm}$ compr., face adaxial e abaxial adpresso curto incano-tomentosa e com tricomas glandulares; corola 4-mera, pétalas livres, obovadas, 2,5-3 mm compr., ápice dos apêndices das pétalas posteriores com crista erosa, emarginada ou biauriculiforme; lobos nectaríferos 4, posteriores ovoides, laterais reduzidos; androginóforo glabro; estames 2,5-3 mm compr., pubescentes; estaminódios, ca. 2 mm compr., ovário trígono-obovoide, 3-carpelar, 3-locular, densamente pubescente, com tricomas glandulares, estilete ca. 0,3 mm compr., pubérulo, estigma trífido, ca. $0,5 \mathrm{~mm}$ compr. Mericarpos samaroides ovado-cordados, $1,8-2 \times 1,8-2$ $\mathrm{cm}$, cartáceos, porção seminífera do mericarpo inflada, com nervuras proeminentes; em nível dos lóculos 6-8 mm larg.; epicarpo da porção seminífera pubescente e das alas pubérulo ou velutino-pubescente; endocarpo com tricomas raros; sementes trígono-elipsoidais, ca. $4 \times 2$ $\mathrm{mm}$, pubérulas na base, cotilédone externo curvo e interno biplicado.

Material examinado: Lima Duarte, Serra Negra, Fazenda Serra Negra, 31.V.2009, fl., J.H.C. Ribeiro \& F.S. Souza 143 (CESJ).

Material adicional: BRASIL. RIO DE JANEIRO: Mangaratiba, Reserva Ecológica Rio das Pedras, Trilha das Borboletas, 13.VII.1997, fr., J.M.A. Braga et al. 4225 (RB); Itatiaia, Parque Nacional de Itatiaia, estrada principal do Parque, BR 485, 612 m alt., S 22 27'45,2”, W 044³5'38,0”, 27.VIII.2009, fr., G.V. Somner et al. 1458 (RBR). SÃO PAULO: Fernandópolis, mata do Zoológico, 26.VI.1993, fl., R. Neves 250 (RB, USU).

Serjania fuscifolia é endêmica do Brasil. Na Serra Negra S. fuscifolia ocorre no campo rupestre em torno de $1.200 \mathrm{~m}$ de altitude. Destaca-se por apresentar o caule em seção transversal composto por um cilindro vascular central pequeno e 8 cilindros vasculares periféricos do mesmo tamanho que o central. Os folíolos possuem margem crenado-serreada, dentes arredondados, e na face adaxial com nervura principal denso castanho-claro-pubescente, e domácias na face abaxial. Os frutos apresentam a porção seminífera dos mericarpos samaroides inflada, pubérula ou pubescente. As sementes são pubérulas na base. Na Serra Negra foi coletada com flores em maio.

11. Serjania laruotteana Cambess. in A. St.-Hil., F1. Bras. merid. 1: 368. $1828 . \quad$ Fig. 6g Nomes populares: cipó-uva, cipó-timbó-açu, erva-timbó.

Liana lactescente, caule 8-10 estriado, jovem pubescente, adulto glabro, em seção transversal composto por um cilindro vascular central e 7-8 cilindros vasculares periféricos. Folhas biternadas; pecíolo canaliculado, ca. $3,5 \mathrm{~cm}$ compr.; raque primária bicanaliculada, secundária marginada; estípulas oblongas, caducas, cicatrizes semilunares; folíolos 2,5-7,5 × 1,3-3 cm, ovadolanceolados, cartáceos, glabros, base atenuada 
e assimétrica, ápice agudo; margem denteadoserreada; domácias pilosas. Tirso racemiforme, pedúnculo $1-9,5 \mathrm{~cm}$ compr., raque $7-12 \mathrm{~cm}$ compr., pubescente; cincinos 4-7-floros; brácteas ovado-triangulares, 0,5 $\mathrm{mm}$ compr., bractéolas triangulares, 0,2 $\mathrm{mm}$ compr. Flores zigomorfas; sépalas 5 , duas externas elípticas, glabras ou pubérulas, ciliadas, tres internas obovadas, 2-3,5 $\mathrm{mm}$ compr, adpresso incano-pubescente; pétalas 4, 3,5-5,5 mm compr., ápice dos apêndices das pétalas posteriores com crista biauriculiforme; lobos nectaríferos 4 , posteriores ovoides, obtusos, laterais elípticos; androginóforo glabro; estames 3-4 mm compr., vilosos; estaminódios ca. 2,5 $\mathrm{mm}$ compr., pistilódio glabro; ovário trígonopiriforme, 3-carpelar, com tricomas glandulares, estilete ca. $2 \mathrm{~mm}$ compr., estigmatrífido, ca. 1 $\mathrm{mm}$ compr. Mericarpos samaroides ca. 2,5 × 1,7 $\mathrm{cm}$, cartáceo, subcordados, porção seminífera do mericarpo achatada lateralmente, em nível dos lóculos 1-1,2 cm larg., epicarpo da porção seminífera com tricomas glandulares e das alas glabro; endocarpo glabro; sementes elipsoides, ca. $5 \times 4 \mathrm{~mm}$, achatadas, glabras, cotilédone curvo e o interno biplicado plicado.

Material examinado: Lima Duarte, Serra Negra, Fazenda Serra Negra, 17.VII.2009, fr., J.A. Oliveira et al. 81 (CESJ); 5.IV.2009, bt, J. Miloski et al. 36 (CESJ). Material adicional examinado: BRASIL. MINAS GERAIS: Ouro Preto, área perto da UFOP, 27.VIII.1986, fr., Acevedo-Rodríguez \& J. Badini 1518 (RB). PARANÁ: Parque Nacional do Iguaçú, 14.V.1949, fr., A.P. Duarte \& E. Pereira 1785 (RB). RIO DE JANEIRO: Itatiaia, Parque Nacional de Itatiaia, BR 485, estrada próxima a ponte do Maromba, 21.V.2010, fl., G.V. Somner et al. 1516 (RBR). SÃO PAULO: Limeira, Fazenda Morro Azul, 12.V.1943, fl., M. Kuhlmann 725 (RB, SP); Reserva Biológica do Parque Estadual das Fontes do Ipiranga, 30.V.1978, fl., H. Makino 133 (RB).

Serjania laruotteana não é endêmica do Brasil, ocorrendo em outros países da América do Sul como Argentina e Paraguai. Na Serra Negra S. laruotteana foi encontrada na borda de floresta estacional semidecidual em torno de $1.200 \mathrm{~m}$ de altitude. Esta espécie vegetativamente é bem semelhante a $S$. multiflora, porém difere desta por apresentar as seguintes características: estípulas oblongas, caducas, com cicatriz semilunar; folíolos com domácias na face abaxial; flores com as sépalas externas glabras ou pubérulas, e as internas incano-tomentosas; mericarpos samaroides com a porção seminífera do mericarpo achatada lateralmente e epicarpo das alas glabro. Na Serra Negra foi coletada com frutos em julho.
12. Serjania laxiflora Radlk.: Monogr. Serjania: 135. 1875 .

Fig. $5 \mathrm{j}-\mathrm{k}$

Nome popular: timbó.

Trepadeira lenhosa, caule 5-estriado, com estrias vináceas, glabro, em seção transversal com apenas um cilindro vascular. Folhas biternadas, pecíolo canaliculado, 1,5-2,6 cm compr.; estípulas triangulares, ca. $0,5 \mathrm{~mm}$ compr.; raque bicanaliculada ou alada; folíolos 1,5-5,5 × 0,8-2,5 $\mathrm{cm}$, ovados ou elípticos, cartáceos, discolores, glabros, base atenuada, obtusa ou assimétrica, ápice agudo ou obtuso, mucronado, margem inteira ou 2-3 denteado-serreada na porção distal, revoluta, face adaxial brilhante, face abaxial opaca; domácias pilosas. Tirso racemiforme, laxifloro, pedúnculo 3,5-9 $\mathrm{cm}$ compr., raque $2,5-7 \mathrm{~cm}$ compr., subglabra; cincinos 4-6-floros; brácteas triangulares, ca. $1,5 \mathrm{~mm}$ compr., ciliadas e com tricomas glandulares. Flores zigomorfas; sépalas 5 , livres, membranáceas, duas externas elípticas, ca. $3 \mathrm{~mm}$ compr., glabrescentes, três internas ovadas ou elípticas, ca. $4 \mathrm{~mm}$ compr., pubérulas; pétalas 4, 4,5-5 mm compr., obovadas, membranáceas, longo unguiculadas, ápice dos apêndices das pétalas posteriores com crista emarginada ou erosa; lobos nectaríferos 4, posteriores subesféricos, lobos laterais reduzidos; androginóforo glabro; estames 3,5-4 mm compr., vilosos; pistilódio glabro; ovário trígono-obovoide, 3-carpelar, com tricomas glandulares; estaminódios 2,5-3 mm compr. Mericarpos samaroides 1,6-2 × 1,4-1,8 $\mathrm{cm}$, cartáceos, ovados a cordiformes, em nível do lóculo ca. $8 \mathrm{~mm}$ larg., porção seminífera pouco inflada, com nervuras proeminentes, epicarpo da porção seminífera e alas glabros, endocarpo viloso, com tricomas longos; sementes lenticulares, 4-5× $3 \mathrm{~mm}$, glabras, cotilédone externo curvo e interno biplicado.

Material examinado: Lima Duarte, Serra Negra, Trilha para o Marciano, 14.X.2008, fl., C.N. Matozinhos et al.421 (CESJ, RBR); Rio Preto, Serra do Funil, Ninho da Égua, 25.IV.2005, fl. e fr., C.N. Matozinhos et al. 195 (CESJ, RBR); Serra Negra, região do Burro de Ouro, 20.V.2006, fl., P.L. Viana et al. 2041 (CESJ, RBR).

Material adicional examinado: BRASIL. MINAS GERAIS, Lima Duarte, nascente do Pirapitinga, 11.X.1989, fl., L. Krieger \& M. Brugger 24264 (CESJ, RBR).

Serjania laxiflora é uma espécie endêmica de Minas Gerais. Na Serra Negra foi encontrada no campo rupestre e em borda de floresta ombrófila densa entre 1.000 e $1.600 \mathrm{~m}$ de altitude. Esta espécie destaca-se por apresentar folíolos com margem inteira ou com 2-3 dentes na porção 
distal, a face adaxial brilhante e face abaxial opaca, com domácias pilosas. A inflorescência possui tirsos laxifloros, característica que deu origem ao seu epíteto específico. Os frutos são glabros e apresentam a porção seminífera do mericarpo pouco inflada, com nervuras proeminentes; as sementes são lenticulares. Na Serra Negra foi coletada com flores de abril a maio e outubro, e com frutos em abril e agosto.

13. Serjania multiflora Cambess. in A. St.-Hil., Fl. Bras. Merid. 1: 365. 1828.

Fig. 51-n

Nomes populares: cipó-timbó, timbó.

Trepadeira lenhosa, densamente tomentosa no pecíolo, raque e eixos da inflorescência; caule 8-10-estriado, glabro; em seção transversal composto por 1 cilindro vascular central e 8 cilindros vasculares periféricos pequenos, menores que o central. Folhas biternadas; estípulas subuladas, ca. $6 \mathrm{~mm}$ compr., hirsutas, persistentes; pecíolo canaliculado, 1,9-6 cm compr; raque marginada ou bicanaliculada; folíolos 3,5-11 $\times$ 2-4,5 cm, ovados a elípticos, cartáceos, brilhantes e castanho-escuros na face adaxial, opacos, castanho mais claros ou castanho-esverdeados na face abaxial, base atenuada, ápice agudo ou acuminado, mucronado; margem denteado-serreada, dentes obtusos ou agudos na metade distal, face adaxial pilosa apenas nas nervuras, face abaxial glabra ou pubescente; domácias ausentes. Tirso espiciforme, pedúnculo 1,3-9 cm compr, raque $2-13 \mathrm{~cm}$ compr., densamente tomentosa, cincinos 3-7-floros; brácteas ovado-triangular ou triangular, ápice obtuso ou acuminado-mucronado, margem com tricomas glandulares. Flores zigomorfas; sépalas 5, livres, duas externas ovadas, 1,5-2,5 mm compr., glabras ou pubescentes, ciliadas, três internas oblongo-elípticas, 2,5-4 mm compr., adpresso denso-incano-pubescente, pétalas 4 , espatuladas, ca. 4,2 mm compr., apêndice das pétalas posteriores com crista emarginada ou bipartida, viloso; lobos nectaríferos 4, posteriores ovoides, obtusos, laterais suborbiculares; androginóforo glabro ou piloso; estames 8, 2,5-5 mm compr., vilosos, anteras rostradas, pistilódio pubescente e com tricomas glandulares; estaminódios 8, 2-2,5 mm compr., ovário trígono-piriforme, 3-carpelar, denso tomentoso, estilete ca. 1,5 mm compr. Mericarpos samaroides, ovado-cordados, 2,3-3,2 × 2,3-2,8 $\mathrm{cm}$, cartáceos; porção seminífera do mericarpo subglobosa, epicarpo da porção seminífera pubérulo ou denso-ferrugíneo-pubescente, alas pubérulas, em nível dos lóculos 5-7 mm larg., crista ca. 0,5 mm compr., endocarpo glabro ou viloso; sementes trígono-piriforme, 3-4,5 × 2-3 $\mathrm{mm}$, glabras, cotilédone externo curvo e interno biplicado.

Material examinado: Rio Preto, Serra Negra, Vila do Funil, 30.VIII.2008, fl. e fr., J. Miloski et al. 6 (CESJ). Material adicional examinado: BRASIL. MINAS GERAIS: Juiz de Fora, Morro do Imperador, 29.VIII.2001, fr., D.S. Pifano \& A.S.M. Valente s.n. (CESJ 34127); Viçosa, Escola, 25.VIII.1930, fr., $M$. Kuhlmann s.n. (RB 137580). SÃO PAULO, Santo Antônio, E.F.S., 24.VI.1935, fl., C. Smith 22 (RB).

Serjania multiflora é uma espécie endêmica do Brasil. Na Serra Negra S. multiflora foi encontrada na borda de floresta ombrófila densa em torno de $900 \mathrm{~m}$ de altitude. Esta espécie é vegetativamente bem semelhante a $S$. laruotteana, porém difere desta por apresentar as seguintes características: folhas com estípulas subuladas, persistentes; folíolos sem domácias na face abaxial; flores com sépalas externas glabras ou pubescentes e as internas tomentosas; mericarpos samaroides com a porção seminífera do mericarpo inflada, epicarpo na porção seminífera pubérulo ou densoferrugíneo-pubescente, alas pubérulas. Na Serra Negra foi coletada com flores em agosto e com frutos em abril e agosto.

14. Serjania reticulata Cambess. in A. St.-Hil., Fl. Bras. Merid. 1: 359. 1828.

Fig. 6i

Nomes populares: cipó-timbó, timbóvermelho.

Trepadeira lactescente; caule 5-6-costado, geniculado, glabro; em seção transversal com apenas um cilindro vascular. Folhas biternadas; estípulas triangulares, ca. 1,5 mm compr., ciliadas, persistentes, pecíolo bicanaliculado, 2,3-6 cm compr.; raque bicanaliculada; folíolos 4-10 $\times$ 1,7-4,2 cm, ovados, obovados ou oblongos, cartáceos; base atenuada ou obtusa; ápice obtusoacuminado, margem denteado-serreada em 1/2-1/3 distal, dentes arredondados, face adaxial brilhante, castanho-escura, glabra, face abaxial opaca, castanho mais clara, glabra a pubescente, geralmente nervuras castanho claras em ambas as faces; domácias ausentes. Tirso racemiforme, pedúnculo $1-1,4 \mathrm{~cm}$ compr., raque $2,7-3,7 \mathrm{~cm}$ compr., pubescente, cincinos 5-6-floros; brácteas triangulares, 0,7-1 $\mathrm{mm}$ compr., pubérulas, margem com tricomas glandulares, bractéolas semelhantes às brácteas, ca. 0,5 mm compr. Flores zigomorfas; sépalas 4, membranáceas, duas externas elíptico-oblongas, ca. $3 \mathrm{~mm}$ compr., 
subglabras ou velutinas, duas internas ovadas, ca. $4 \mathrm{~mm}$ compr., tomentosas; pétalas 4, obovadas, 4-5 mm compr., glandulosas, apêndice das pétalas posteriores com crista emarginada ou bipartida; lobos nectaríferos 4, posteriores ovoides, laterais subesféricos, reduzidos; androginóforo glabro; estames 2,5-3,5 mm compr., pilosos na base, anteras rostradas; estaminódios, 2-2,5 mm compr.; ovário trígono-obovoide, 3-carpelar, com tricomas glandulares, estilete 1,2-1,5 mm compr, estigma trífido, ca. 0,7 mm compr.. Mericarpos samaroides subcoriáceos, 1,8-2,5 × 1,2-2,2 cm, ovado-cordados, em nível dos lóculos 6-8 mm larg.; porção seminífera do mericarpo inflada, raro com crista dorsal estreita, epicarpo da porção seminífera e alas glabro; endocarpo incanolanoso; sementes trígono-obovoides, 3-4 × 3 $\mathrm{mm}$, glabras, cotilédone externo curvo e interno biplicado.

Material examinado: Lima Duarte, RPPN Serra Negra, 20.IV.2009, fl. e fr., L. Menini Neto et al. 672 (CESJ, RBR); Monte Verde de Cima, Serra Negra, fazenda Serra Negra, 11.V.2008, fr., N.L. Abreu \& L. Menini Neto 229 (CESJ, RBR).

Material adicional examinado: BRASIL. MINAS GERAIS: Belo Horizonte, III.1963, fl., E. Pereira 7297 (RB); Barroso, Mata do Baú, 13.IV.2001, fr., L.C.S. Assis \& M.K. Ladeira 62 (CESJ, RBR).

Serjania reticulata não é endêmica do Brasil, ocorrendo também nos países da América do Sul como Bolívia e Argentina. Na Serra Negra foi coletada em borda de floresta estacional semidecidual a cerca de $1.200 \mathrm{~m}$ de altitude. Esta espécie se diferencia das demais espécies estudadas por apresentar as seguintes características: caule geniculado, em seção transversal com apenas um cilindro vascular; folíolos com margem denteadoserreada em 1/2-1/3 distal, geralmente nervuras castanho claras em ambas as faces e domácias ausentes na face abaxial; flores com anteras rostradas. Na Serra Negra foi coletada com flores de dezembro a julho e com frutos de abril a agosto e dezembro.

Dentre as 14 espécies registradas para Serra Negra 11 são endêmicas do Brasil, ocorrendo tanto nos campos rupestres como nas diferentes formações florestais. As espécies de distribuição mais ampla são: Allophylus semidentatus, $C$. vernalis, $P$. trigonia, $S$. fuscifolia, $S$. multiflora e $S$. reticulata, sendo que $C$. vernalis, $S$. laruotteana e $S$. reticulata não são endêmicas do Brasil, ocorrendo em outros países da América do Sul. A espécie com distribuição mais restrita é Serjania laxiflora, endêmica de Minas Gerais.
A comparação da flora de Sapindaceae da Serra Negra com outras áreas de Minas Gerais demonstra um grau variável de compartilhamento de espécies. Ferrucci (2006) encontrou para a região de Grão Mogol 14 espécies, com apenas quatro comuns às duas áreas: Matayba juglandifolia, M. marginata, Paullinia carpopoda e Serjania reticulata. No Parque Estadual do Ibitipoca Forzza et al. (2013) registraram seis espécies com apenas duas compartilhadas, $C$. vernalis e $M$. marginata. $\mathrm{Na}$ região do entorno deste parque Valente et al. (2013) relacionaram 11 espécies, das quais sete são encontradas na Serra Negra. Para a Serra do Cipó Silva et al. (2013) registraram 39 espécies, incluindo todas aquelas registradas na Serra Negra. Na Serra de São José Alves \& Kolbek (2009) registraram apenas três espécies, compartilhando com a Serra Negra apenas a presença de Cupania vernalis.

\section{Agradecimentos}

Os autores agradecem à FAPEMIG (Processos CRA 1891/06, CRA-APQ 1810-5.02/07, APQ 03507-09), CNPq (Processo 551462/2008-6), o auxílio financeiro. Ao pesquisador do Royal Botanic Gardens, Kew, Simon Mayo, a revisão do abstract. À Universidade Federal de Juiz de Fora (UFJF), a colaboração da infraestrutura.

\section{Referências}

Acevedo-Rodríguez, P. 1993. Systematics of Serjania (Sapindaceae). Part I: A revision of Serjania Sect. Platycoccus. The New York Botanical Garden, New York. 94p.

Acevedo-Rodríguez, P.; van Welzen, P.C.; Adema, F.; van der Ham, R.W.J.M. 2010. Sapindaceae. In: Kubitzki, K. (ed.). The families and genera of vascular plants. Vol. 10. Springer, Berlin. Pp. 369-448.

Acevedo-Rodríguez, P. 2012. Flora of the Guianas: Sapindaceae. Series: A Phanerogams Fascicle 29. The Trustees of the Royal Botanic Gardens, Kew. $196 \mathrm{p}$.

Alves, R.J.V. \& Kolbek, J. 2009. Summit vascular flora of Serra de São José, Minas Gerais, Brazil. Check List 5: 35-73.

APG IV. 2016. An update of the Angiosperm Phylogeny Group classification for the orders and families of flowering plants: APG IV. Botanical Journal of the Linnean Society 181: 1-20.

BFG. 2015. Growing knowledge: an overview of seed plant diversity in Brazil. Rodriguésia 66: 1085-1113.

Buerki, S.; Forest, F.; Acevedo-Rodríguez, P.; Callmander, M.W; Nylander J.A.A.; Harrington M.; Sanmartín I.; Küpfer P. \& Alvarez, N. 2009. Plastid and nuclear DNA markers reveal intricate 
relationships at subfamilial and tribal levels in the soapberry family (Sapindaceae). Molecular Phylogenetics and Evolution 51: 238-258.

Coelho, R.L.G. 2008. Estudos taxonômicos em Matayba Aubl. sect. Matayba (Sapindaceae). Dissertação de Mestrado. Universidade Estadual de Campinas, São Paulo. 170p.

Costa, C. \& Herrmann, G. 2006. Plano de ação do Corredor Ecológico da Mantiqueira. Valor Natural, Belo Horizonte. 64p.

Drummond, G.M.; Martins, C.S.; Machado, A.B.M.; Sebaio, F.A. \& Antonini, Y. 2005. Biodiversidade em Minas Gerais: Um atlas para sua conservação. $2^{\mathrm{a}}$ ed. Fundação Biodiversitas, Belo Horizonte. 222p.

Ferrucci, M.S. 1991. Flora del Paraguay (Sapindaceae). In: Spichiger, R. \& Ramella, L. (eds.). Conservatoire et Jardin Botaniques de la Ville de Genéve (Genéva). Missouri Botanical Garden, St. Louis. Pp. 18-144.

Ferrucci, M.S. 2006. Flora do Grão-Mogol, Minas Gerais: Sapindaceae. Boletim da Universidade de São Paulo 24: 79-86.

Filgueiras, T.S.; Nogueira, P.E.; Brochado, A.L. \& Guala, G.F. 1994. Caminhamento: um método expedito para levantamentos florísticos qualitativos. Cadernos de Geociências 12: 39-43.

Forzza, R.C.; Menini Neto, L, Salimena, F.R.G. \& Zappi, D. 2013. Fanerógamas do Parque Estadual do Ibitipoca e suas relações florísticas com outras áreas com campo rupestre de Minas Gerais. In: Forzza, R.C.; Menini Neto, L.; Salimena, F.R.G. \& Zappi, D. (orgs.). Flora do Parque Estadual do Ibitipoca e seu entorno. UFJF, Juiz de Fora. Pp. 153-291.

Gadek, P.A.; Fernando, E.S.; Quinn, C.J.; Hoot, S.B.; Terrazas, T.; Sheahan, M.C. \& Chase, M.W. 1996. Sapindales: molecular delimitation and infraordinal groups. American Journal of Botany 83: 802-811.

Guarim Neto, G. 1994. Sapindaceae. In: Rizzo, J.A. (coord.). Flora dos estados de Goiás e Tocantins. Coleção Rizzo, Vol. 16. Ed. UFG, Goiânia. 61p.

Guarim Neto, G. \& Santana, S.R. 2000. A família Sapindaceae para flora do estado do Mato Grosso do Sul, Brasil. III Simpósio sobre Recursos Naturais e Sócio-econômicos do Pantanal. Os Desafios do Novo Milênio. 46p.

Harrington, M.G.; Edwards, K.J.; Johnson, S.A.; Chase, M.W. \& Gadek, P.A. 2005. Phylogenetic inference in Sapindaceae sensu lato using plastid $m a t K$ and $r b c L$ DNA sequences. Systematic Botany 30: 366-382.

Judd, W.S.; Campbell, C.S.; Kellog, E.A. \& Stevens, P.F. 2009. Sapindaceae. In: Judd, W.S.; Campbell, C.S.;
Kellog, E.A. \& Stevens, P.F. (eds.). Sistemática vegetal: um enfoque filogenético. $3^{\text {a }}$ ed. Artmed, Porto Alegre. Pp. 438-440.

Menini Neto, L.; Matozinhos, C.N.; Abreu, N.L.; Valente, A.S.M.; Antunes, K.; Soares, F.S.; Viana, P.L. \& Salimena, F.R.G. 2009. Flora vascular não-arbórea de uma floresta de grota na Serra da Mantiqueira, Zona da Mata de Minas Gerais, Brasil. Biota Neotropica 9: 149-161.

Pirani, J.R \& Cortopassi-Laurino, M. 1993. Flores e Abelhas em São Paulo. Edusp, São Paulo. 192p.

Radford, A.E. 1974. Fundamentals of plant systematics. Harper \& Row, New York. 507p.

Radlkofer, L. 1931-1934. Sapindaceae. In: Engler, A. (ed.). Das Pflanzenreich. Leipzig, Wilhelm Engelmann, IV-165, Heft 98a-h, Pp. 1-1539, f. 1-46.

Reitz, R. 1980. Sapindáceas. In: Flora ilustrada catarinense. Herbário Barbosa Rodrigues, Itajaí. $156 \mathrm{p}$.

Salimena, F.R.G.; Matozinhos, C.N.; Abreu, N.L.; Ribeiro, J.H.C.; Souza, F.S. \& Menini Neto, L. 2013. Flora fanerogâmica da Serra Negra, Minas Gerais, Brasil. Rodriguésia 64: 311-320.

Silva, K.F.; Ferrucci, M.S. \& Groppo, M. 2013. Flora da Serra do Cipó, Minas Gerais: Sapindaceae. Boletim de Botânica da Universidade de São Paulo 31: 99-130.

Somner, G.V. 2001. Paullinia L. (Sapindaceae): Morfologia, taxonomia e revisão de Paullinia sect. Phygoptilon. Tese de Doutorado. Universidade de São Paulo, São Paulo. 235p.

Somner, G.V.; Carvalho, A.L.G. \& Siqueira, C.T. 2009. Sapindaceae da Restinga da Marambaia, Rio de Janeiro, Brasil. Rodriguésia 60: 485-507.

Somner, G.V.; Ferrucci, M.S.; Rosa, M.M.T. \& Coelho, R.L.G. 2009. Sapindaceae. Somner, G.V. (coord.). In: Wanderley, M.G.L.; Shepherd, G.J.; Melhem, T.S.; Giulietti, A.M. \& S.E. Martins (coords.). Flora fanerogâmica do estado de São Paulo. Instituto de Botânica, Fapesp/Imprensa Oficial, São Paulo. Vol. 6, pp. 195-255.

Souza, F.S.; Salino, A.; Viana, P.L. \& Salimena, F.R.G. 2012. Pteridófitas da Serra Negra, Minas Gerais, Brasil. Acta Botanica Brasilica 26: 378-390.

Valente, A.S.M.; Araújo, F.S.; Fontes, M.A.L. \& Rocha, G.C. 2013. O entorno do Parque Estadual do Ibitipoca: fitofisionomias e lista florística. In: Forzza, R.C.; Menini Neto, L.; Salimena, F.R.G. \& Zappi, D. (orgs.). Flora do Parque Estadual do Ibitipoca e seu entorno. UFJF, Juiz de Fora. Pp. 293-347. 


\section{Lista de exsicatas}

Abreu, N.L. \& Menini Neto, L. 229 - CESJ, RBR (14). Abreu, N.L. et al. 87 - CESJ (5), 159 - CESJ (7). Acevedo-Rodríguez \& Badini, J. 1518 - RB (11). Almeida, V.C. 146 - R, RBR (2). Alves, R.J.V. \& Abreu, N.L. 8762 - CESJ (7). Antunes, K. \& Alves, R.J.V. 405 - CESJ (9). Antunes, K. et al. 55 - CESJ (7), 58 - CESJ (1), 105 - CESJ (6), 133 - CESJ (8). Assis, L.C.S. \& Ladeira, M.K. 62 - CESJ, RBR (14). Braga, J.M.A. et al. 4225 - RB (10). Cavalcanti, D.C. 188 - HRCB, RBR (1). Duarte, A.P. \& Pereira, E. 1785 - RB (11). Farney, C. \& Gomes, J.C. 4069 - RB, RBR (1). Krieger, L. \& Urbano, C. 8731 - CESJ (8), RBR; Krieger, L. \& Brugger, M. 24264 - CESJ, RBR (12). Kuhlmann, M. 725 -RB, SP (11), s.n. - RB 137580 (13). Makino, H. 133 - RB (11). Matozinhos, C.N. et al. 32 - CESJ (6), 58 - CESJ, SPRF (7), 64 - CESJ, SPFR (5), 90 - CESJ (9), 195 - CESJ, RBR (12), 326 - CESJ (9), 421 - CESJ, RBR (12). Menini Neto, L. et al. 670 - CESJ (6), 672 - CESJ, RBR (14). Miloski, J. et al. 1 - CESJ (3), 2 - CESJ (4), 3 - CESJ (5), 5 - CESJ, SPRF (6), 6 - CESJ (13), 36 - CESJ (11). Monteiro, D. et al. 537 - CESJ (9). Neves, R. 250 - RB, USU (10). Oliveira, J.A. et al. 81 - CESJ (11), 85 - CESJ (5). Oliveira, R.C. 23480 - CESJ (6). Pavão, O.C. et al. s.n. - FUEL, RBR 9453 (3). Pereira, E. 7297 - RB (14). Pifano, D.S. \& Valente, A.S.M. s.n. - CESJ 34127 (13). Ribeiro, J.H.C. \& Souza, F.S. 143 - CESJ (10). Ribeiro, J.H.C. et al. 22 - CESJ (5), 168 - CESJ (2), 238 - CESJ (5). Robim, M.J. 687 - RBR, SPSF (1). Roman, S.A. et al. 20 - CESJ (9), 23 - CESJ (6). Salimena, F.R.G. \& Nobre, P.H. 2430 - CESJ (7), 2465 - CESJ (9). Salimena, F.R.G. et al. 1117 - CESJ (6), 1144 - CESJ (5), 1370 - CESJ (6), 2472 - CESJ (5), 3591 - CESJ (5), 3600 - CESJ (7). Schwacke 13670 - RB (1). Smith, C. 22 - RB (13). Somner, G.V. et al. 1301 - RBR (3), 1453 - RBR (8), 1458 - RBR (10), 1516 - RBR (11), 1518 - RBR (9). Souza, F.S. \& Bastos, O.J. 524 - CESJ (9). Souza, F.S. \& Ribeiro, J.H.C. 678 - CESJ (6). Souza, F.S. et al. 281 - CESJ (4). Stehmann, J.R. et al. 3681 - BHCB, RBR (7). Valente, A. et al. 252 - CESJ (2), 347 - CESJ (3), 350 - CESJ (1). Valente, A.S.M. \& Garcia, P.O. s.n. - CESJ 49344 (4). Viana, P.L. et al. 2041 - CESJ, RBR (12), 2157 - CESJ (9). 